ISSN 1660-3397

www.mdpi.com/journal/marinedrugs

Article

\title{
Co-Processed Chitin-Mannitol as a New Excipient for Oro-Dispersible Tablets
}

\section{Nidal Daraghmeh ${ }^{1,2}$, Babur Z. Chowdhry ${ }^{2}$, Stephen A. Leharne ${ }^{2}$, Mahmoud M. H. Al Omari ${ }^{1}$ and Adnan A. Badwan 1,*}

1 The Jordanian Pharmaceutical Manufacturing Co., PO Box 94, Naor 11710, Jordan;

E-Mails: nidalda@hotmail.com (N.D.); momari@jpm.com.jo (M.M.H.O.)

2 Faculty of Engineering \& Science, University of Greenwich, Medway Campus, Chatham Maritime Kent ME44TB, UK; E-Mails: b.z.chowdhry@greenwich.ac.uk (B.Z.C.); s.a.leharne@greenwich.ac.uk (S.A.L.)

* Author to whom correspondence should be addressed; E-Mail: jpm@go.com.jo; Tel.: +962-6-5727-207; Fax: +962-6-5727-641.

Academic Editor: David Harding

Received: 2 November 2014 / Accepted: 9 February 2015 / Published: 30 March 2015

\begin{abstract}
This study describes the preparation, characterization and performance of a novel excipient for use in oro-dispersible tablets (ODT). The excipient (Cop-CM) consists of chitin and mannitol. The excipient with optimal physicochemical properties was obtained at a chitin: mannitol ratio of $2: 8(\mathrm{w} / \mathrm{w})$ and produced by roll compaction (RC). Differential scanning calorimetry (DSC), Fourier transform-Infrared (FT-IR), X-ray powder diffraction (XRPD) and scanning electron microscope (SEM) techniques were used to characterize Cop-CM, in addition to characterization of its powder and ODT dosage form. The effect of particle size distribution of Cop-CM was investigated and found to have no significant influence on the overall tablet physical properties. The compressibility parameter (a) for Cop-CM was calculated from a Kawakita plot and found to be higher (0.661) than that of mannitol (0.576) due to the presence of the highly compressible chitin (0.818). Montelukast sodium and domperidone ODTs produced, using Cop-CM, displayed excellent physicochemical properties. The exceptional binding, fast wetting and superdisintegration properties of Cop-CM, in comparison with commercially available co-processed ODT excipients, results in a unique multifunctional base which can successfully be used in the formulation of oro-dispersible and fast immediate release tablets.
\end{abstract}


Keywords: crystalline mannitol; $\alpha$-chitin; roll compaction; oro-dispersible tablets

\section{Introduction}

Tablets are widely used as drug delivery system due to their convenience with respect to self-administration and ease of manufacture [1]. Various excipients are used in their preparation [2]. However, pediatric, geriatric and mentally ill patients experience difficulties in swallowing conventional tablets, which leads to poor patient compliance. To overcome this deficiency, ODT formulations have been developed $[3,4]$.

In Ph. Euro., an ODT is defined as a tablet to be placed in the mouth where it disperses rapidly before being swallowed in less than 3 minutes [5], while the FDA considers it as a solid oral preparation that disintegrates rapidly in the oral cavity with an in vivo disintegration time of approximately $30 \mathrm{~s}$ or less [4]. ODTs are advantageous due to their administration without water, rapid onset of action and improved bioavailability [6,7].

Various ODT patented technologies such as Orasolv/DuraSolv (by direct compression (DC)), Zydis (by freeze drying), FlashTab (Eudragit-microencapsulation and effervescent couple), FlashDose (cotton candy process) and WowTab (compression moulding process) have been commercialized [8,9]. ODTs are highly friable, due to their compaction at lower crushing force compared to conventional tablets, resulting in rapid disintegration; therefore, they are commonly packed in special packaging materials, which add to their cost [10]. A high level of superdisintegrant (up to $20 \% \mathrm{w} / \mathrm{w}$ ) is usually needed in ODT preparations in order to enhance their disintegration properties. Additional excipients including a suitable filler, binder, lubricant, sweetener and color may be added to improve product properties [6,11].

Mannitol, in crystalline, granulated, or spray dried form is widely used in ODT tablet formulations due to its sweet, cool taste and compatibility with a wide range of drugs [12-14]. Unlike crystalline mannitol, spray dried mannitol is highly compactible, non-friable, and quick dissolving, which facilitate its use in DC formulations of ODTs. Furthermore, crystalline mannitol is widely used in tablet wet granulation (WG) processes due to its favourable cost [15-17].

Chitin is used as chromatographic supports and adsorbents for industrial pollutants [18,19], for recovery of silver thiosulfate complexes [20], enzyme immobilization [21], wound healing [22], fibers and film formers [23], and binders in the paper making process [15]. Recently, chitin has been used as a starting material to produce pyranoside [24] and furan [25] derivatives. Furthermore, chitin monomer $\mathrm{N}$-acetyl-D-glucosamine has been used as a source of amide/amino substituted sugar alcohols [26].

Chitin is used in tablet formulations because it is non-toxic, non-allergenic, anti-microbial, non-reactive and biodegradable. Its disintegration power is mainly dependent upon a high water uptake rate. Therefore, chitin can be used over a higher concentration range than many commercially available disintegrants without negatively affecting other tablet properties. However, chitin powder shows poor compactibility, which has limited its applications in commercialized dosage forms [27,28]. To overcome this shortcoming, chitin was co-processed with other excipient modifiers in order to facilitate its handling in solid dosage form manufacturing. As with other excipients, co-processing is carried out using different manufacturing techniques such as spray drying or melt extrusion [29]. For example, chitin, a plastic 
material, has been successfully used to prepare different excipients via co-processing with diverse brittle materials including mannitol, metal silicates and silicon dioxide [30-32]. In all cases co-processing was achieved by incorporating the brittle material $(\leq 30 \% \mathrm{w} / \mathrm{w})$ inside the pores of chitin $(\geq 70 \% \mathrm{w} / \mathrm{w})$ using an aqueous vehicle. The result of the foregoing studies showed that the extremely large surface pores of chitin measured by BET analysis [31,33,34] were not fully accommodated by the guest materials and thus chitin preserved its functionality as a disintegrant. Moreover, the co-processed excipients enhanced the physical properties, functionality and performance (e.g., no-hygroscopicity and highly compactable/ disintegrable) of tablet preparations [30-32]. A combination of chitin, chitosan-alginate (1:1), and glycine was reported in preparation of a novel superdisintegrant [35]. The forgoing excipient was applied to formulate sulbutamol sulphate ODT by using direct compression. This may offer a valuable practical industrial addition in terms of superdisintegration and mechanical properties of ODT formulations. Furthermore, an article describing the characterization and application of such a novel co-processed excipient in immediate release tablet formulations has been reported in the literature [32]. In the aforementioned study, the tablets prepared by using the co-processed excipient chitin:mannitol $(80: 20 \mathrm{w} / \mathrm{w})$ and different drugs displayed excellent chemical stability, binding, and disintegration properties. This may extend its application to ODTs [32].

The objective of the work reported herein is to test the possibility of using co-processed chitin-mannitol as a single excipient in producing ODTs. This may help to overcome the problem of low crushing strength inherited from other techniques and to use chitin for the first time as the main excipient allowing the use of conventional industrial machinery for the production and packaging of ODTs.

\section{Results and Discussion}

\subsection{Selection of Processing Methods and Ratios for Co-Processed Chitin-Mannitol Excipient}

In order to select the optimal ratio and process for co-processed excipient preparation, three different ratios of chitin and mannitol (10:90, 20:80 and 30:70 w/w) and three different processing techniques i.e., direct mixing, $\mathrm{WG}$ and $\mathrm{RC}$ were used. The prepared excipients were lubricated with sodium stearyl fumarate $(1.0 \% \mathrm{~W} / \mathrm{w})$ and compressed at different tablet crushing forces $(50-150 \mathrm{~N})$. The tablets obtained were tested for friability, disintegration and wetting times versus the corresponding crushing forces. The preliminary results of the aforementioned experiments indicated that direct mixing and WG were unsuitable, because the mixtures prepared by direct mixing displayed unacceptable physical properties (e.g., poor flow and powder non-uniformity). The difference in bulk densities of chitin $\left(\sim 0.2 \mathrm{~g} / \mathrm{cm}^{3}\right)$ and mannitol $\left(\sim 0.5 \mathrm{~g} / \mathrm{cm}^{3}\right)$ is the reason underlying such unacceptable physical properties. In the case of WG, the tablets suffered from capping and high disintegration times due to penetration of the dissolved mannitol into the chitin pores. Such penetration does not allow the pores to act as functional compression and disintegration enhancers. However, RC gave reasonable results. The data in Figure 1 shows the effect of crushing force on the friability, disintegration and wetting times of tablets produced. Up to a crushing force of $90 \mathrm{~N}$, all chitin:mannitol ratios showed acceptable physical properties (low friability and fast disintegration and wetting times). While at crushing forces above $90 \mathrm{~N}$, the excipient prepared by using a chitin:mannitol ratio of 1:9 showed capping upon tablet compression due to an insufficient amount of chitin, responsible for improving the compressibility. Using chitin:mannitol ratios of 2:8 and 
3:7 (w/w) over all the investigated range of crushing forces produced tablets with acceptable physical properties. However, a ratio of chitin and mannitol of 2:8 $(\mathrm{w} / \mathrm{w})$ was chosen in order to obtain beneficial mannitol taste properties and to reduce the amount of insoluble chitin in ODT preparations.
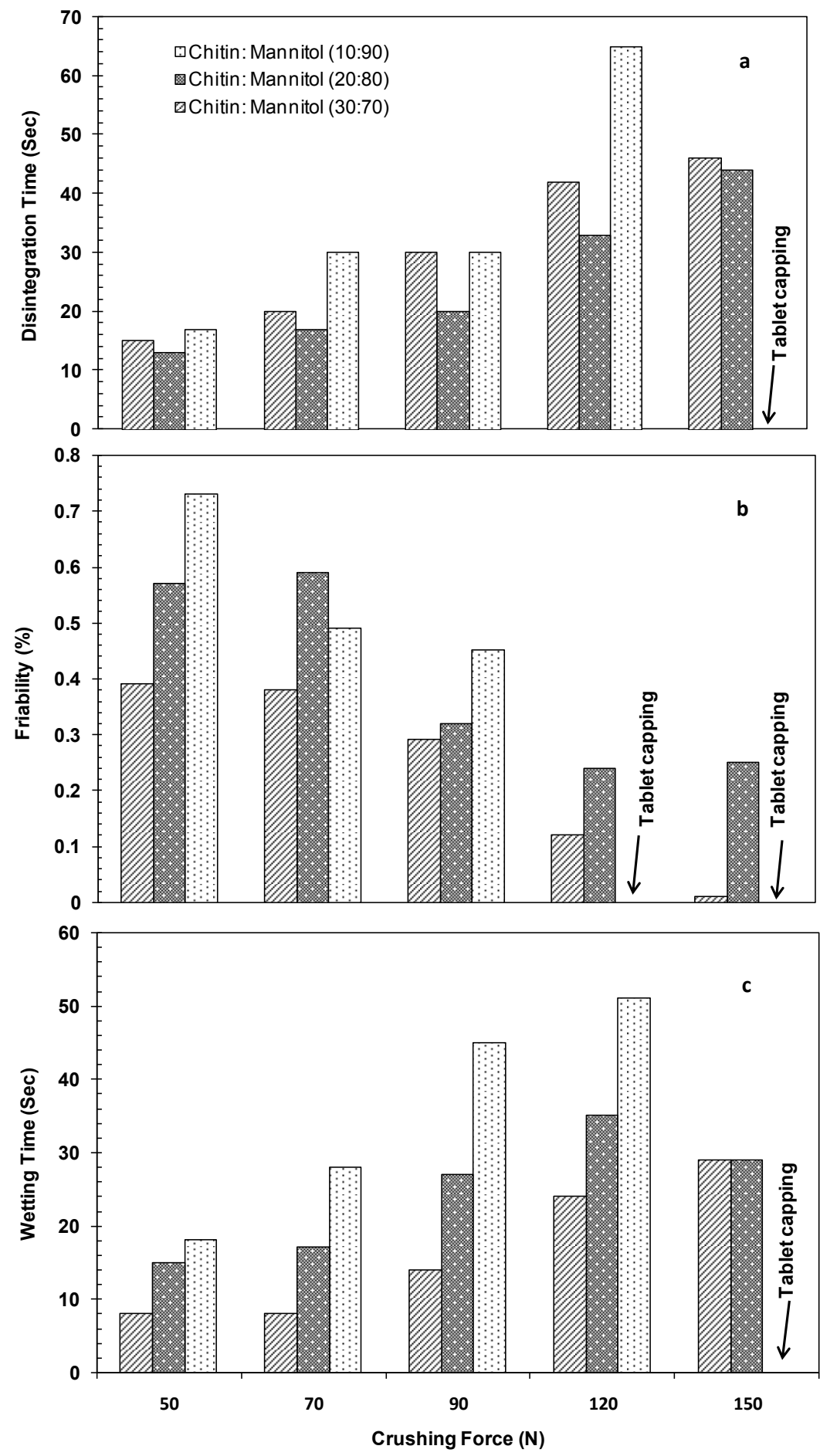

Figure 1. Plots of the crushing force $(\mathrm{N})$ versus (a) disintegration time; (b) friability; and (c) wetting time for compacted mixtures prepared using different ratios of chitin and mannitol $(1: 9,2: 8$, and 3:7 w/w). Tablets were $10 \mathrm{~mm}$ in diameter and $250 \mathrm{mg}$ in weight. All powders were lubricated using $1 \%(\mathrm{w} / \mathrm{w})$ sodium stearyl fumarate. 


\subsection{Characterization of Cop-CM Powder}

The FT-IR spectra of chitin, mannitol, the corresponding physical mixtures and Cop-CM are presented in Figure 2.

It is clear that the FT-IR spectrum of the physical mixture of chitin and mannitol (Figure 2c) is a superimposition of the vibrational band profiles contributed by chitin and mannitol (Figure 2a,b). The dominance of the principal bands of mannitol in the physical mixture is a result of its high fractional composition in the mixture $(80 \% \mathrm{w} / \mathrm{w})$. The two bands in the $1550-1660 \mathrm{~cm}^{-1}$ range, corresponding to the amide I and II vibrational modes of chitin (Figure 2a), persist in the spectra of the physical mixture and Cop-CM, while the remaining bands are due to mannitol. The absence of any shift in the FT-IR bands of Cop-CM (Figure 2d), in comparison with the bands of the physical mixture (Figure 2c), suggests the absence of chemical interaction due to the use of RC to form Cop-CM.

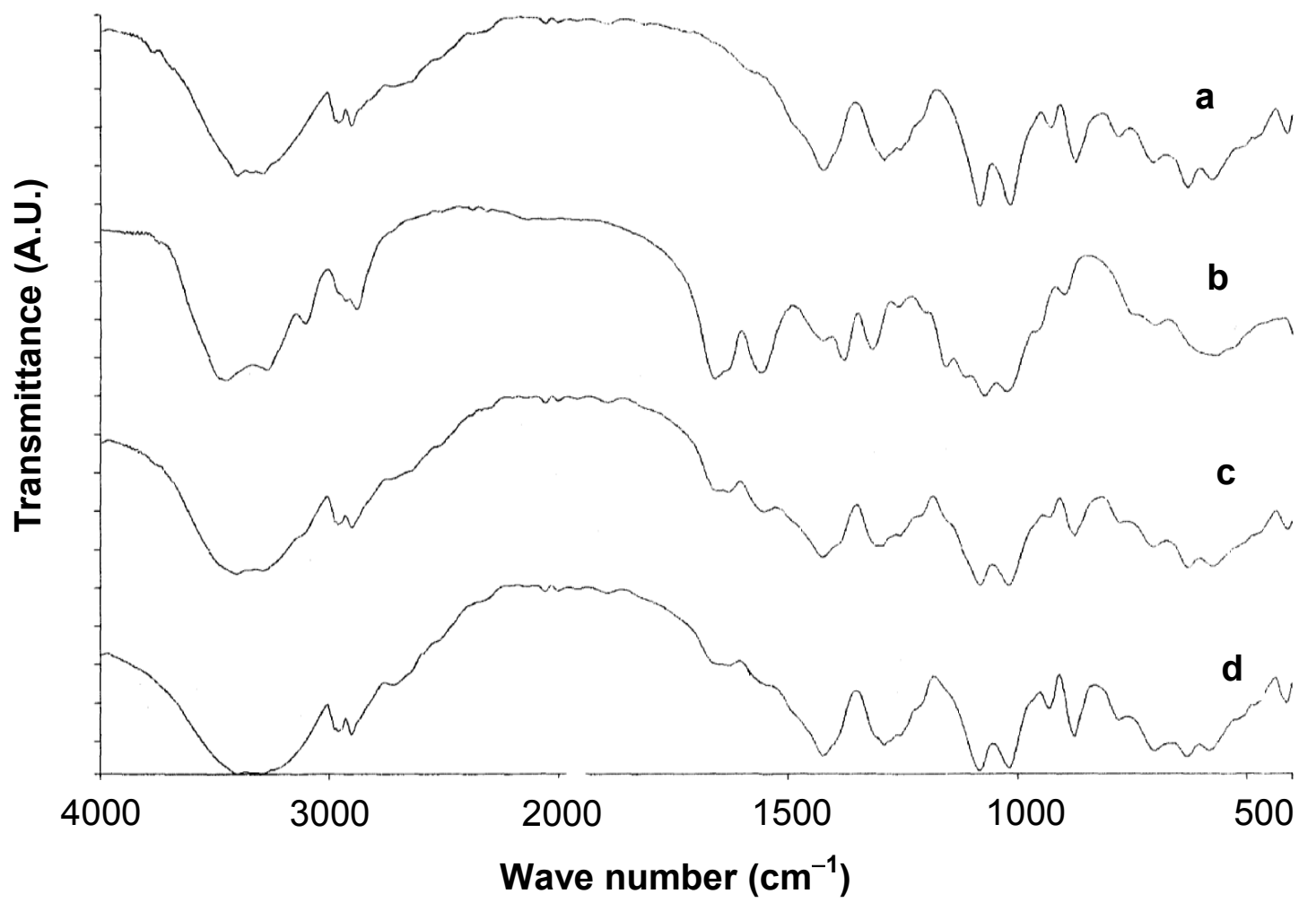

Figure 2. FT-IR spectra of (a) mannitol; (b) chitin; (c) physical mixture of chitin-mannitol $(2: 8, \mathrm{w} / \mathrm{w})$; and (d) co-processed chitin-mannitol (2:8 w/w) excipient (Cop-CM).

Further analysis of Cop-CM by XRPD (Figure 3) and DSC (Figure 4) techniques showed the same results, where the signals corresponding to mannitol are dominant due to its high fractional content and crystallinity. The two broad peaks of chitin appeared at $2 \theta$ of around 11 and 22 but not clearly well-defined in both the physical mixture and Cop-CM due to the low content of chitin in the mixtures. The absence of new bands or shifts in the patterns indicates the absence of formation of a new crystal form or chemical interaction. This property is essential for such co-processed excipient to work as an excipient. 


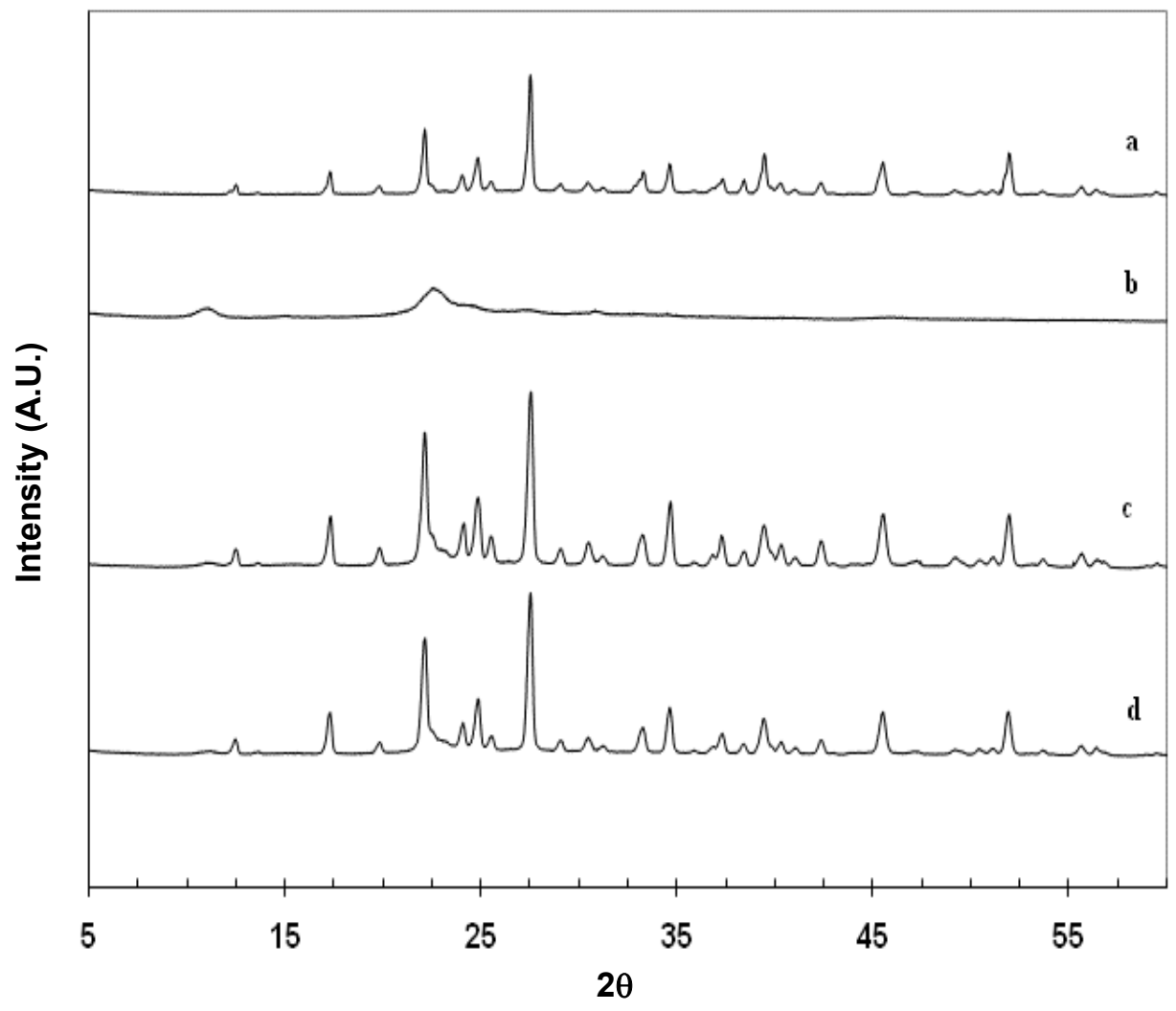

Figure 3. XRPD profiles of (a) mannitol; (b) chitin; (c) physical mixture of chitin-mannitol (2:8, w/w); and (d) co-processed chitin-mannitol (2:8 w/w) excipient (Cop-CM).

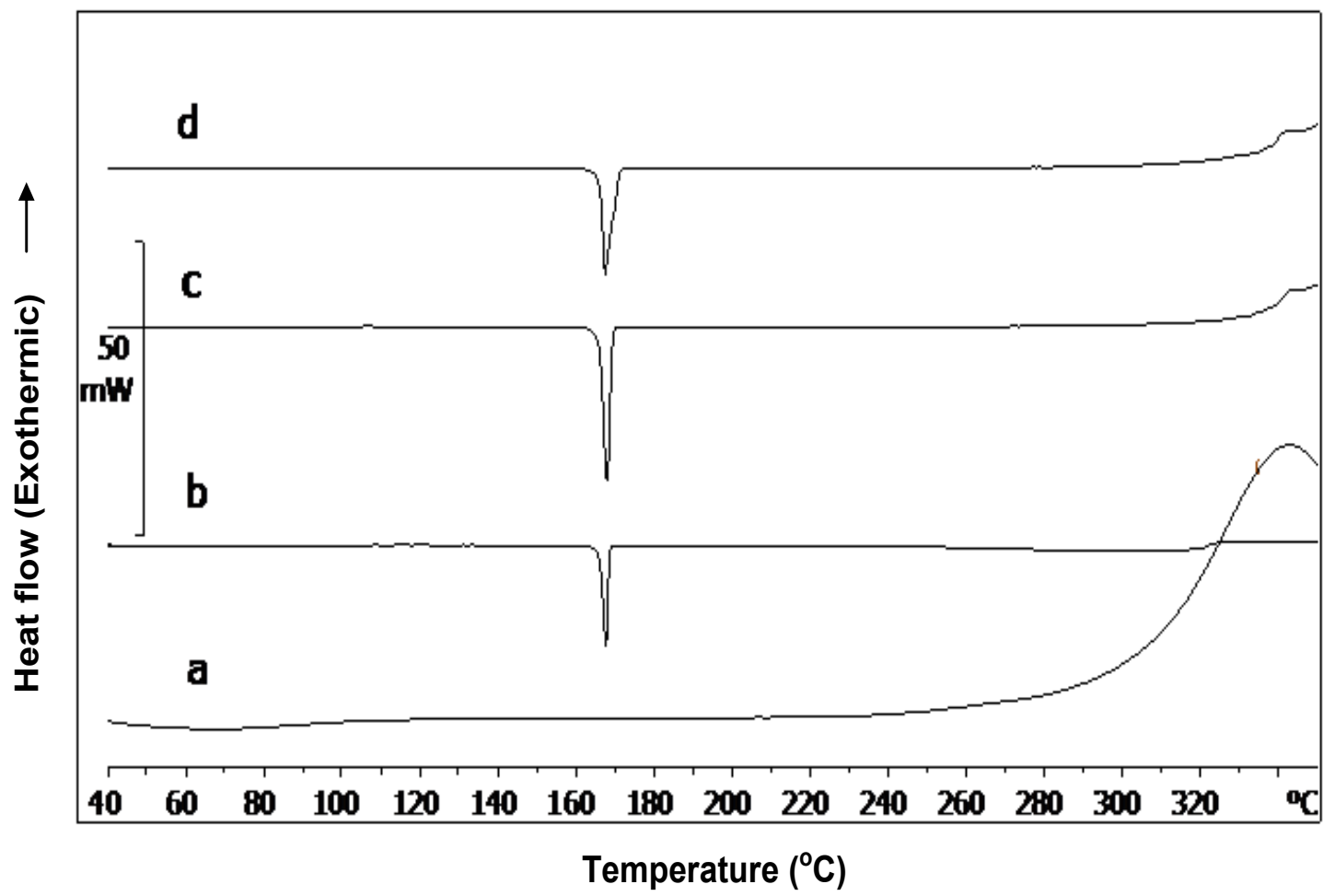

Figure 4. DSC thermograms of (a) chitin; (b) mannitol; (c) physical mixture of chitin-mannitol $(2: 8, \mathrm{w} / \mathrm{w})$ and $(\mathbf{d})$ co-processed chitin-mannitol $(2: 8 \mathrm{w} / \mathrm{w})$ excipient (Cop-CM). 
SEM was used to investigate particle surface morphology (Figure 5). When comparing the particle shape of mannitol (Figure 5a) with that of Cop-CM (Figure 5d), it is apparent that it has changed from rectangular rod granules to three-dimensional dense compacts for Cop-CM.

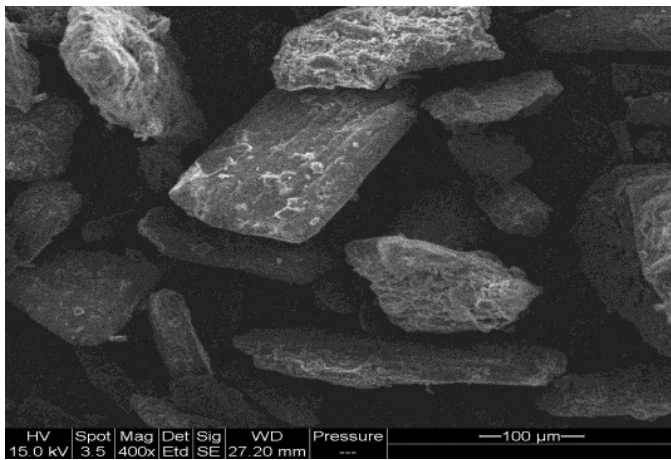

(a)

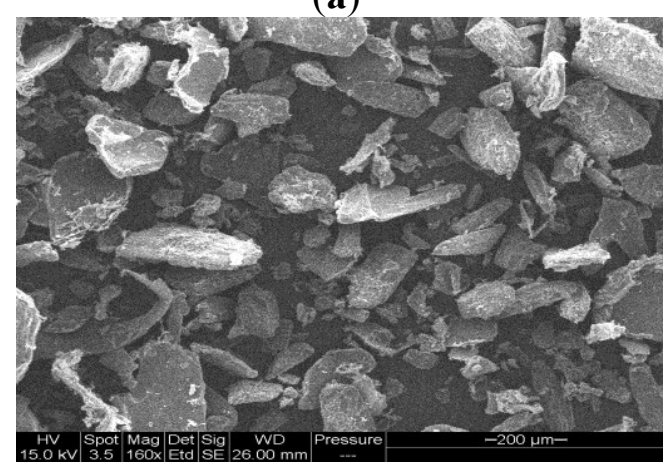

(c)

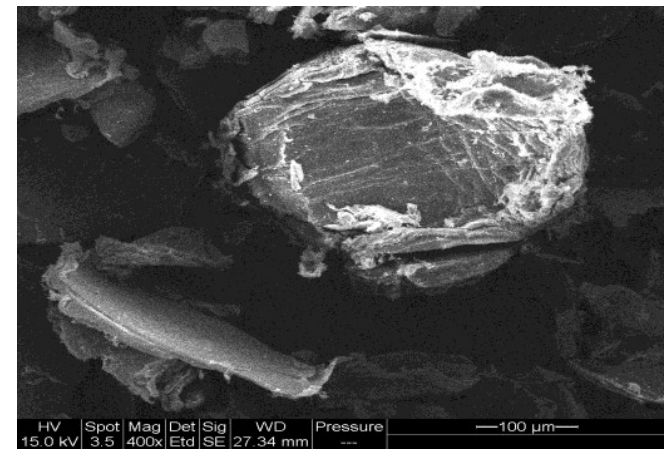

(b)

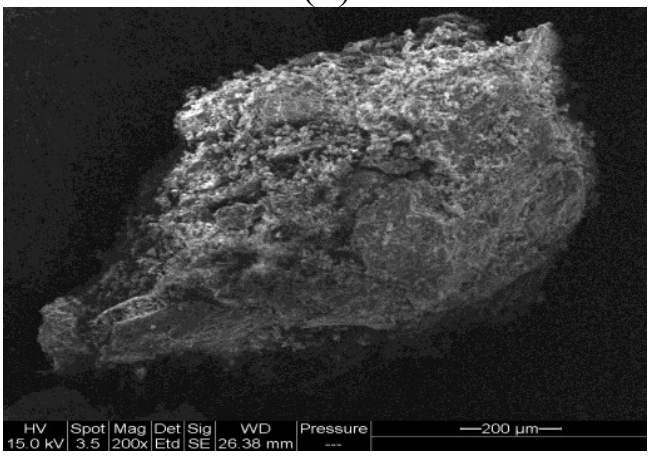

(d)

Figure 5. SEM images of (a) mannitol; (b) chitin; (c) physical mixture of chitin-mannitol $(2: 8, \mathrm{w} / \mathrm{w})$; and (d) co-processed chitin-mannitol $(2: 8 \mathrm{w} / \mathrm{w})$ excipient (Cop-CM).

\subsection{Physical Properties of Cop-CM Powder}

The physical properties of Cop-CM powders which passed through two different mesh size sieves (710 and $1000 \mu \mathrm{m})$ were evaluated. The two powders have a water content of about $1.5 \% \mathrm{w} / \mathrm{w}$ and a bulk density of $0.5-0.55 \mathrm{~g} / \mathrm{cm}^{3}$. The $\mathrm{pH}$ of a $5 \%(\mathrm{w} / \mathrm{v})$ aqueous dispersion is in the range $6-8$. The particle size distribution (D10, D50 and D90) of Cop-CM is given in Table 1.

Particle size and shape are critical parameters in powder characterization, particularly in DC formulations affecting powder performance, packing, consolidation, flowability and compaction. It is one of the prime considerations in selecting excipients to develop and optimize a pharmaceutical formulation. Ideally, DC excipients should exhibit narrow size distributions with moderate-to-coarse particle, having a mean particle size of 100-200 $\mu \mathrm{m}$ [36]. In ODT formulations, the control of particle size is essential for the water insoluble excipients to minimize the feeling of grittiness during tablet administration. The best results are obtained when using a smaller particle size for insoluble excipients. Another critical parameter for the DC excipient is the bulk density which can be used to describe the packing behavior of granules [36]. Cop-CM powder passed through a mesh size of $710 \mu \mathrm{m}$ has a mean particle size of about $215 \mu \mathrm{m}$. A higher bulk density is advantageous in tabletting because of a reduction 
in the powder-fill volume of the die. Cop-CM powder sieved through a mesh size of $1000 \mu \mathrm{m}$ has a bulk density of about $0.52 \mathrm{gm} / \mathrm{mL}$ and a tapped density of $0.59 \mathrm{gm} / \mathrm{mL}$.

Table 1. The physical properties of co-processed chitin-mannitol (2:8 w/w) excipient (Cop-CM).

\begin{tabular}{ll}
\hline Parameter & Value \\
\hline Water content $(\mathrm{w} / \mathrm{w} \%)$ & 1.5 \\
$\mathrm{pH}$ & $6.0-8.0$ \\
Bulk density $(\mathrm{gm} / \mathrm{mL})$ & $0.50-0.55$ \\
Tapped density $(\mathrm{gm} / \mathrm{mL})$ & $0.55-0.65$ \\
Particle size distribution: & \\
- Milling through $710 \mu \mathrm{m}$ & $\mathrm{D} 10: 5 \mu \mathrm{m}$; D50: $145 \mu \mathrm{m}$; D90: $496 \mu \mathrm{m}$ \\
- Milling through $1000 \mu \mathrm{m}$ & $\mathrm{D} 10: 7 \mu \mathrm{m}$; D50: $170 \mu \mathrm{m}$; D90: $584 \mu \mathrm{m}$ \\
Hausner Ratio & 1.13 \\
Carr Index & 11.86 \\
Angle of Repose & $32^{\circ}$ \\
\hline
\end{tabular}

On the other hand, Hausner Ratio $(H)$ is an indirect index of ease of powder flow. It is calculated by using the formula [37]

$$
H=\frac{T D}{B D}
$$

where $\mathrm{TD}$ and $\mathrm{BD}$ are the tapped and bulk densities, respectively.

The simplest method of measurement of free flow of a powder is compressibility; an indication of the ease with which material can be induced to flow is given by Carr Index $(I)$ which is calculated using the formula:

$$
I=100 \frac{(T D-B D)}{T D}
$$

Carr Index of $\leq 10$ indicates excellent flow, whereas $I$ values of $11-15$ indicate good flow. Hausner Ratio of 1.0-1.11 indicates excellent flow whereas values of 1.12-1.18 indicate good flow (generally lower Carr Index and Hausner Ratio values represent better flow).

The change in density before and after tapping calculated as \% compressibility (Carr Index) is an indicator of how fast granules can flow to their highest packing. The Carr Index calculated from the density data showed a value less than 12, and Hausner ratio of less than 1.13 further indicating the good flowability, which is an important factor for DC powders. Good flowability of powder is needed for content uniformity and less weight variation in the final tablets. According to US Pharmacopeia 31, General Chapter $<1174>$, an Angle of Repose of $25-30^{\circ}$ indicates excellent flow, and $31-35^{\circ}$ indicates good flow. The Hausner Ratio, Carr Index and Angle of Repose values for Cop-CM powder are shown in Table 1. From the data obtained, Cop-CM powder showed good flowability and compressibility.

\subsection{Moisture Uptake by Cop-CM}

The data in Figure 6 shows the water uptake by Cop-CM and commercial ODT bases (Phrmaburst C1, Isomalt 721, and Mannogem EZ) at $25{ }^{\circ} \mathrm{C}$ and different relative humidity. With up to $84 \%$ relative humidity for two weeks, all bases, except Pharmaburst $\mathrm{C} 1$, showed an insignificant increase in water 
uptake (Figure 6a). However, following equilibration for one day at $25{ }^{\circ} \mathrm{C} / 45 \%$ relative humidity, Pharmaburst $\mathrm{C} 1$ lost the excess water absorbed (9\%) to reach only $0.7 \%$ (Figure $6 \mathrm{~b}$ ). At high relative humidity (95\%), the water uptake follows the order: Cop-CM $(8 \%)<$ Mannogem EZ $(14 \%)<$ Pharmaburst $\mathrm{C} 1(46 \%)<$ Isomalt galenIQ ${ }^{\mathrm{TM}} 721(66 \%)$. Following equilibration for 1 day at $25{ }^{\circ} \mathrm{C} / 45 \%$ relative humidity, all bases except Isomalt galenIQ ${ }^{\mathrm{TM}} 721$ lost the excess water absorbed to give values less than $1 \%$ (Figure $6 \mathrm{~b}$ ). The relative humidity of Isomalt galenIQ ${ }^{\mathrm{TM}} 721$ it is about $14 \%$ which is most probably due to partial dissolution of Isomalt at high relative humidity.

The difference in water uptake of different bases is due to the difference in their components and their morphology (e.g., crystalline versus amorphous). It seems that the $\mathrm{RC}$ of a large amount of mannitol $(80 \% \mathrm{w} / \mathrm{w})$ with chitin results in the coverage of the outer surface of chitin with mannitol; thus, Cop-CM powder is clearly non-hygroscopic due to the very minimal water uptake of mannitol.
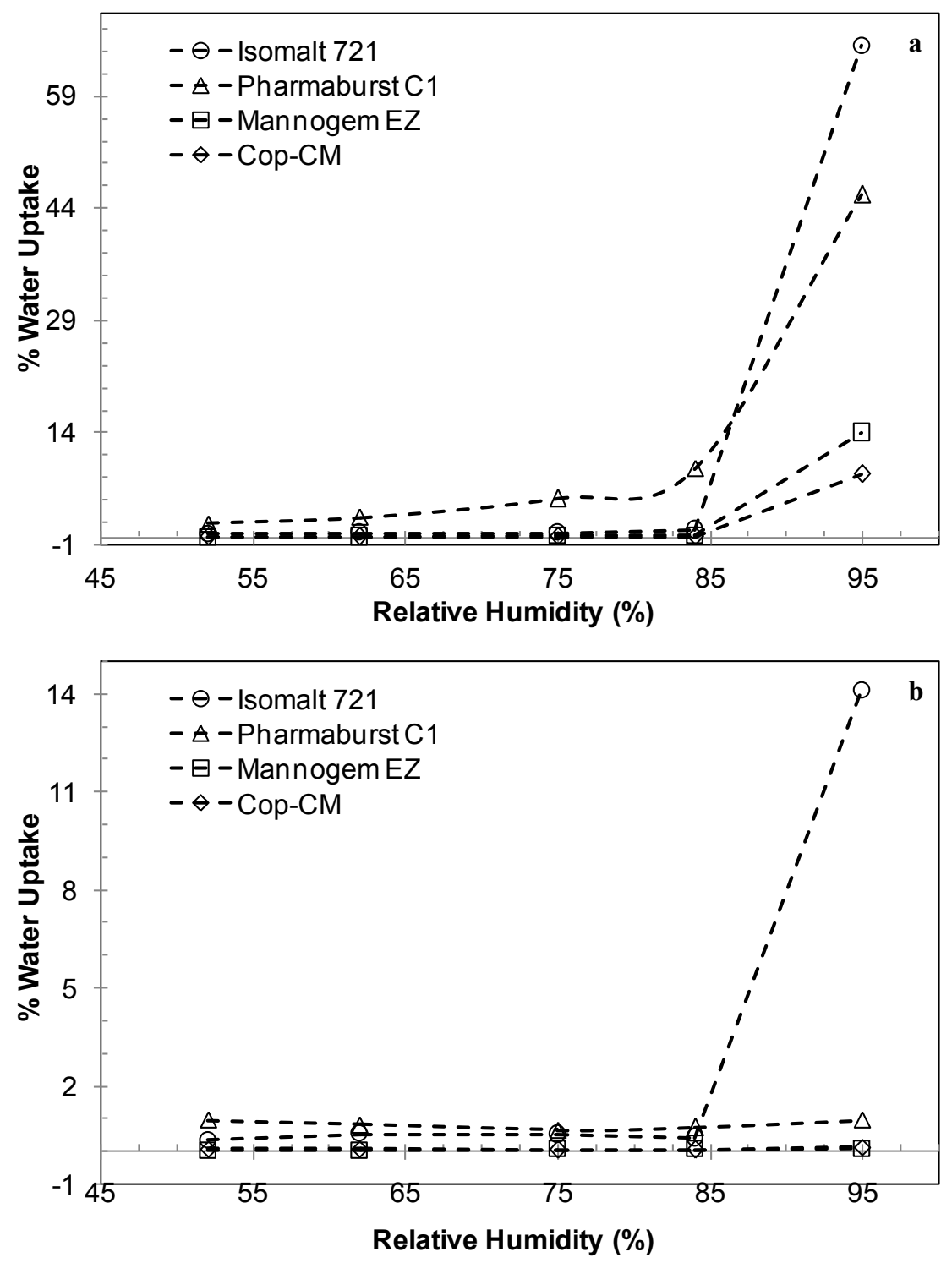

Figure 6. The water uptake by co-processed chitin-mannitol $(2: 8 \mathrm{w} / \mathrm{w})$ excipient (Cop-CM) in comparison with some commercially available ODT bases after incubation at $25{ }^{\circ} \mathrm{C}$ and different relative humidity, (a) for two weeks; and (b) after equilibration at $25{ }^{\circ} \mathrm{C} / 45 \%$ relative humidity for one further day. 


\subsection{Hygroscopicity of Tablets Prepared from $\mathbf{C o p}-\boldsymbol{C M}$}

The water adsorption study was conducted for tablets prepared from $\mathbf{C o p}-\mathbf{C M}$ at $75 \%$ relative humidity and room temperature. Results indicate that the tablets prepared from Cop-CM sorb very little, if any, water (less than $0.4 \% \mathrm{w} / \mathrm{w}$ ). It is advantageous, in the pharmaceutical industry, to use non-hygroscopic ODT preparations, as this will reduce the cost of packaging which is usually used for moisture protection. Needless to say, wetting and ability to disintegrate must prevail.

\subsection{Compression Profile of Tablet Prepared from Cop-CM}

Data for the friability, disintegration and wetting times versus the corresponding crushing force for tablets prepared using Cop-CM powders which passed through either the $710 \mu \mathrm{m}$ or $1000 \mu \mathrm{m}$ sieves are shown in Figure 7. Generally, a reduction in particle size is associated with an increase in tablet mechanical strength. The increase in mechanical strength of the tablets is directly related to its physical properties (crushing force, disintegration time, friability, wetting time, etc.) and attributed to an increase in the surface area available for inter-particulate attraction [38]. However, when Cop-CM was used it was found that varying the particle size had no impact on the mechanical strength of the tablets. The mechanical strength of the tablets prepared from materials with a tendency to fragment, such as mannitol, dibasic calcium phosphate dihydrate and saccharose appear to be independent of particle size [39]. This could be the case for Cop-CM particles which contain an excess amount of mannitol $(80 \% \mathrm{w} / \mathrm{w})$ and undergo fragmentation [40] at the early stages of compression, thereby causing a minimal effect on tablet mechanical strength when varying the particle size.

The disintegration time of ODTs is generally less than one minute and the actual disintegration time that patients expect is less than $30 \mathrm{~s}$. The general compendial method for performing disintegration tests for ODTs is not capable of detecting such a short disintegration time. The wetting time of the ODT is another important test, which gives an insight into the disintegration properties of the tablets. A lower wetting time indicates a quicker disintegration of the tablets [41]. With respect to tablet disintegration, Cop-CM showed a unique characteristic whereby tablet disintegration time was independent of particle size and tablet crushing force (Figure 7). Tablets produced from Cop-CM powders which passed through either the $710 \mu \mathrm{m}$ or $1000 \mu \mathrm{m}$ sieves, at an upper punch compression scale of $16-20 \mathrm{kN}$ for each particle size, showed a superior disintegration time ranging from 11.5 to $59 \mathrm{~s}$ and from 14 to $64 \mathrm{~s}$, respectively. This was achieved for tablet crushing force values ranging from 50 to $150 \mathrm{~N}$. By increasing the crushing strength from 50 to $150 \mathrm{~N}$, the wetting time of the tablet was increased from 9 to $35 \mathrm{~s}$. This suggests that capillary action is the dominant mechanism for the disintegration of Cop-CM which is irrespective of the tablet crushing force [32]. In addition, the inter-particulate voids within the chitin particles in Cop-CM, as previously mentioned, remain intact and unchanged after using the RC procedure with mannitol and by varying the powder particle size. With respect to powder compressibility, chitin within Cop-CM mixture provides an effective means of obtaining hard tablets with low friability while persisting in its fast disintegration and wetting properties, as can be concluded from the data shown in Figure 7. 

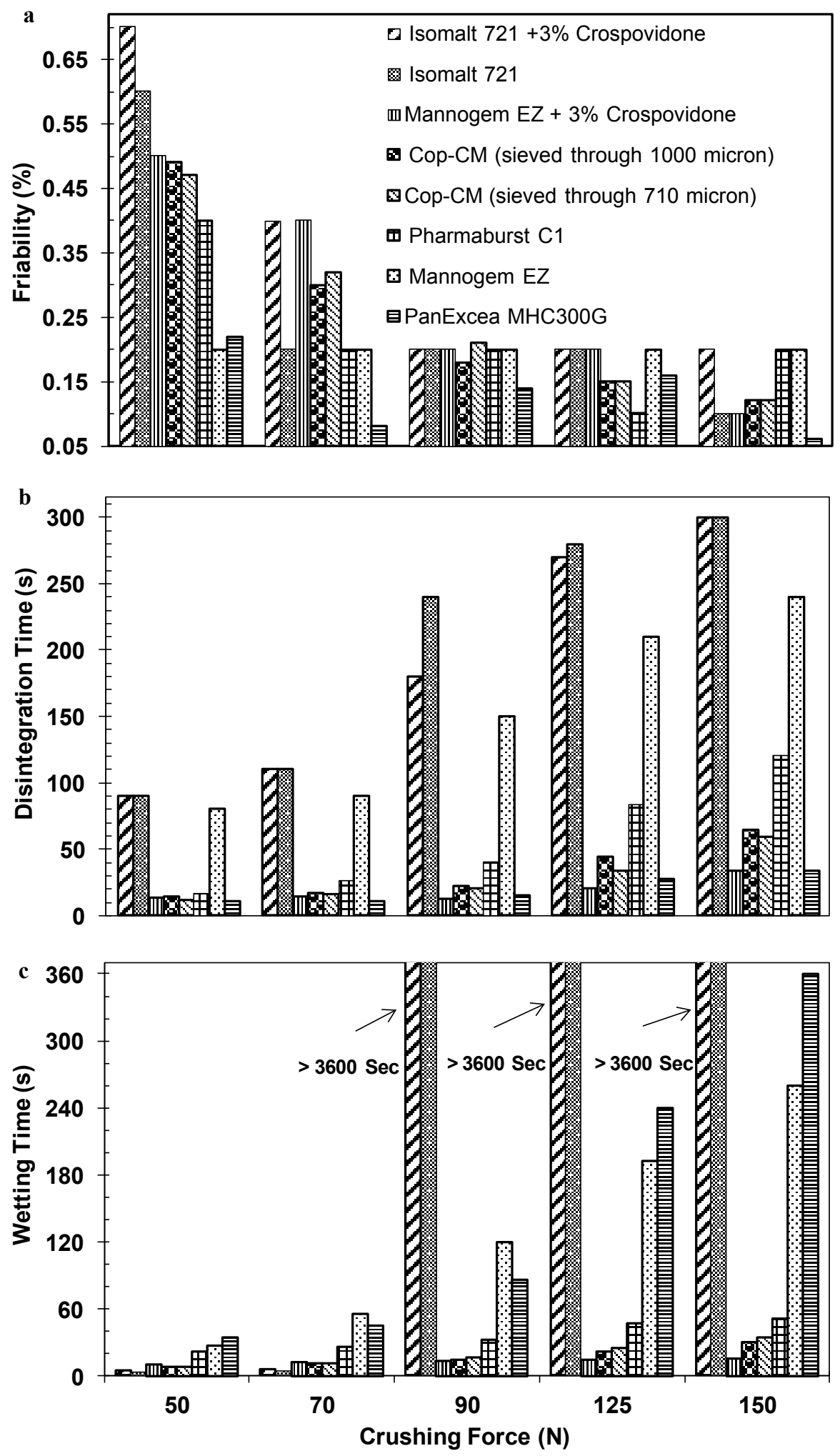

Figure 7. Plots of the crushing force $(\mathrm{N})$ versus (a) friability; (b) disintegration time; and (c) wetting time for tablets prepared using co-processed chitin-mannitol $(2: 8 \mathrm{w} / \mathrm{w})$ excipient (Cop-CM) which passed through either $710 \mu \mathrm{m}$ or $1000 \mu \mathrm{m}$ sieves in comparison with commercially available bases. The tablets were $10 \mathrm{~mm}$ in diameter and $250 \mathrm{mg}$ in weight. All samples were lubricated with $1 \%(\mathrm{w} / \mathrm{w})$ sodium stearyl fumarate. 
Four commercially available ODT excipients were used for comparison purposes including, Isomalt galenIQ ${ }^{\text {TM }}$ 721, Mannogem EZ, Pharmabust EZ and PanExcea MHC200G. The data in Table 2 shows the function and composition of these excipients. Crospovidone, a cross-linked polymer of $\mathrm{N}$-vinyl-2pyrrolidinone, is often used at concentrations up to 5.0\% [11]. In this study, it was used as disintegrant in tablet preparations at 3\% w/w level in both Isomalt galenIQ ${ }^{\mathrm{TM}} 721$ and Mannogem EZ powders. Both PanExcea MC200G and Pharmaburst C1 already contain calcium silicate and crospovidone as disintegrant in their compositions, respectively.

Table 2. Function and composition of commercial oro-dispersible tablet excipients.

\begin{tabular}{|c|c|c|c|}
\hline Trade Name & Composition & Manufacturer & Advantages \& Function \\
\hline $\begin{array}{l}\text { PanExcea } \\
\text { MC200G }\end{array}$ & $\begin{array}{c}\text { Mannitol }(75 \%), \\
\text { calcium silicate }(25 \%) \text {. } \\
\text { Particle size: } 50 \% \\
(103 \mu \mathrm{m})\end{array}$ & $\begin{array}{l}\text { Avantor Performance Materials, } \\
\text { Inc./Center Valley, PA, USA } \\
\text { http://www.avantormaterials.com/ }\end{array}$ & $\begin{array}{l}\text { High performance, rapid } \\
\text { disintegration, direct compression } \\
\text { excipient for oro-dissolving tablets } \\
\text { formulation } \\
\end{array}$ \\
\hline $\begin{array}{c}\text { Mannogem }^{\mathrm{TM}} \\
\text { EZ }\end{array}$ & $\begin{array}{c}\text { Spray dried direct } \\
\text { compression mannitol } \\
\text { Particle size: } 60 \% \\
(75-150 \mu \mathrm{m})\end{array}$ & \multirow{2}{*}{$\begin{array}{c}\text { SPI Pharma }{ }^{\mathrm{TM}} \text {, Inc., } \\
\text { New Castel, DE, USA } \\
\text { http://www.spipharma.com }\end{array}$} & $\begin{array}{c}\text { Assist in formulating } \\
\text { difficult to use } \\
\text { non-hygroscopic ODT containing } \\
\text { fine drugs }\end{array}$ \\
\hline $\begin{array}{c}\text { Pharmaburst TM } \\
\text { C1 }\end{array}$ & $\begin{array}{l}\text { Mannitol } 84 \% \text {, } \\
\text { crospovidone } 16 \% \text {, } \\
\text { silicon dioxide }<1 \%\end{array}$ & & $\begin{array}{c}\text { High compactibility, } \\
\text { high loading in small diameter } \\
\text { tablets, smooth mouth feel, } \\
\text { rapid disintegration }\end{array}$ \\
\hline $\begin{array}{c}\text { Isomalt } \\
\text { galenIQ-721 }\end{array}$ & $\begin{array}{l}\text { 1-O-D-glucopyranosyl-D- } \\
\text { mannitol dehydrate and } \\
\text { 6-O-D-glucopyranosyl-D- } \\
\text { sorbitol }(1: 3) \\
\text { Particle size: } 90 \% \\
(360 \mu \mathrm{m}), 50 \%(220 \mu \mathrm{m})\end{array}$ & $\begin{array}{l}\text { BENEO_Palatinit GmbH (Mannheim, } \\
\text { Germany) } \\
\text { http://www.beneo-- } \\
\text { palatinit.com/en/Pharma_Excipients } \\
\text { _galenIQ/galenIQ_Grades/galenIQ721/ }\end{array}$ & $\begin{array}{l}\text { Highly soluble agglomerated } \\
\text { spherical isomalt for fast } \\
\text { dissolving and very fast } \\
\text { disintegrating direct compression } \\
\text { tablet preparations }\end{array}$ \\
\hline
\end{tabular}

In order to obtain a tablet crushing force in the range of 50-150 N, upper punch compression scales of 25.50-29.5 kN were applied to all excipients except for PanExcea in which case a scale range from 39 to $42 \mathrm{kN}$ was applied. For all reference excipients used, increasing the crushing force from 50 to $150 \mathrm{~N}$ leads to a linear increase in the disintegration and wetting time of the tablets. The friability of the tablets was found to be within the acceptable limit [42] (less than $0.7 \%$ for Isomalt galenIQ ${ }^{\mathrm{TM}} 721$ and $3 \%$ crospovidone) at the lower crushing force $(50 \mathrm{~N})$. Increasing tablet crushing force leads to decrease the friability (less than $0.2 \%$ ). The reference excipients except for Mannogem EZ and Isomalt galenIQ ${ }^{\mathrm{TM}}$ 721 (with and without crospovidone) gave a disintegration time of less than $30 \mathrm{~s}$ at $50 \mathrm{~N}$ tablet crushing force. In addition, the wetting time for all reference excipients was less than $30 \mathrm{~s}$ at the same crushing force. The data in Figure 7 clearly shows that by increasing the tablet crushing force, the disintegration times and wetting times were increased accordingly. Only, Isomalt galenIQ ${ }^{\mathrm{TM}} 721$ plus crospovidone and PanExcea MC200G tablets showed a short disintegration time (less than $33 \mathrm{~s}$ ) at the highest crushing force $(150 \mathrm{~N})$, whereas for the other excipients a disintegration time range of 120-300 s were observed. At a tablet crushing force of $150 \mathrm{~N}$, only pharmaburst $\mathrm{C} 1$ and Mannogem EZ plus crospovidone showed a short wetting time of less than $60 \mathrm{~s}$ (52 and $16 \mathrm{~s}$, respectively). 
For Cop-CM, it can be clearly observed that increasing the tablet crushing force up to $150 \mathrm{~N}$ does not affect both disintegration and wetting times. This property is extremely advantageous where hard tablets with very fast disintegration can be prepared using Cop-CM and simply packed in traditional packaging materials. This prevents the need of a special type of packaging to avoid the breakage of the tablets during removal from the package. A combination of Mannogem ${ }^{\mathrm{TM}} \mathrm{EZ}$ and $3 \%$ crospovidone has showed similar behavior to Cop-CM at high tablets crushing forces. PanExcea MHC300G has preserved the very short disintegration time at $150 \mathrm{~N}$ tablet crushing force, while the tablet wetting time was increased. On the other hand, Pharmaburst $\mathrm{C} 1$ behaves in a different manner, whereby increasing the tablet crushing force to $150 \mathrm{~N}$ the disintegration time was relatively high $(>2 \mathrm{~min})$, while the tablet wetting time was not affected.

\subsection{Powder Compressibility}

The Kawakita equation (Equation (3)) is used to study powder compression using the degree of volume reduction, $\mathrm{C}$. The basis for the Kawakita equation for powder compression is that particles subjected to a compressive load in a confined space are viewed as a system in equilibrium at all stages of compression, so that the product of the pressure term and the volume term is a constant [43]:

$$
C=\frac{\left(V_{o}-V\right)}{V_{0}}=\frac{a b P}{1+b P}
$$

where, $V_{o}$ is the initial volume and $V$ is the volume of powder column under an applied pressure, $P$. The constants $a$ and $b$ represent the minimum porosity before compression and plasticity of the material, respectively. The reciprocal of $b$ defines the pressure required to reduce the powder bed by $50 \%[44,45]$. Equation (3) can be re-arranged in linear form as:

$$
\frac{P}{C}=\frac{P}{a}+\frac{1}{a b}
$$

The expression for particle rearrangement can be affected simultaneously by the two Kawakita parameters $a$ and $b$. The combination of these into a single value, i.e. the product of the Kawakita parameters $(a b)$, may hence be used as an indicator of particle rearrangement during compression [46].

Figure 8 shows the Kawakita plots for mannitol, Cop-CM and chitin. The Kawakita constants $a, b$, $a b$ and $1 / b$ were calculated from the intercept and slope of the plots (Table 3). The constant $a$, which represents the compressibility, is the highest for chitin $(a=0.818)$ and this is due to the large internal surface pores. The compressibility of Cop-CM is higher than mannitol alone $(a=0.661$ and 0.576 , respectively) and this is ascribed to the addition of the chitin to mannitol. This result emphasizes the fact that although the mannitol constitutes $80 \%$ of Cop-CM content, using RC techniques in the preparation of Cop-CM keeps the large chitin surface pores unoccupied and active. This is because mannitol physically adheres at the outer chitin surfaces.

The increase in the $a b$ value for Cop-CM (0.0592), which is a measure of the extent of particle rearrangement, indicates that the addition of chitin has improved the degree of particle rearrangement and packing during tabletting. The $1 / b$ parameter is an inverse measure of the amount of plastic deformation occurring during the compression process $[31,47]$. Generally, a low value of $1 / b$ is a reflection of the soft nature of the material and that the material is readily deformed plastically under 
pressure [48]. Chitin is a highly porous material and forms intermolecular hydrogen bonds between adjacent plastic, deformed chitin particles. The presence of moisture within the porous structure of chitin enforces the formation of hydrogen bond bridges which increase the internal binding upon compaction. Therefore, the use of a smaller amount of chitin (20\%) with mannitol within Cop-CM decreases plastic deformation during compression [31,49].

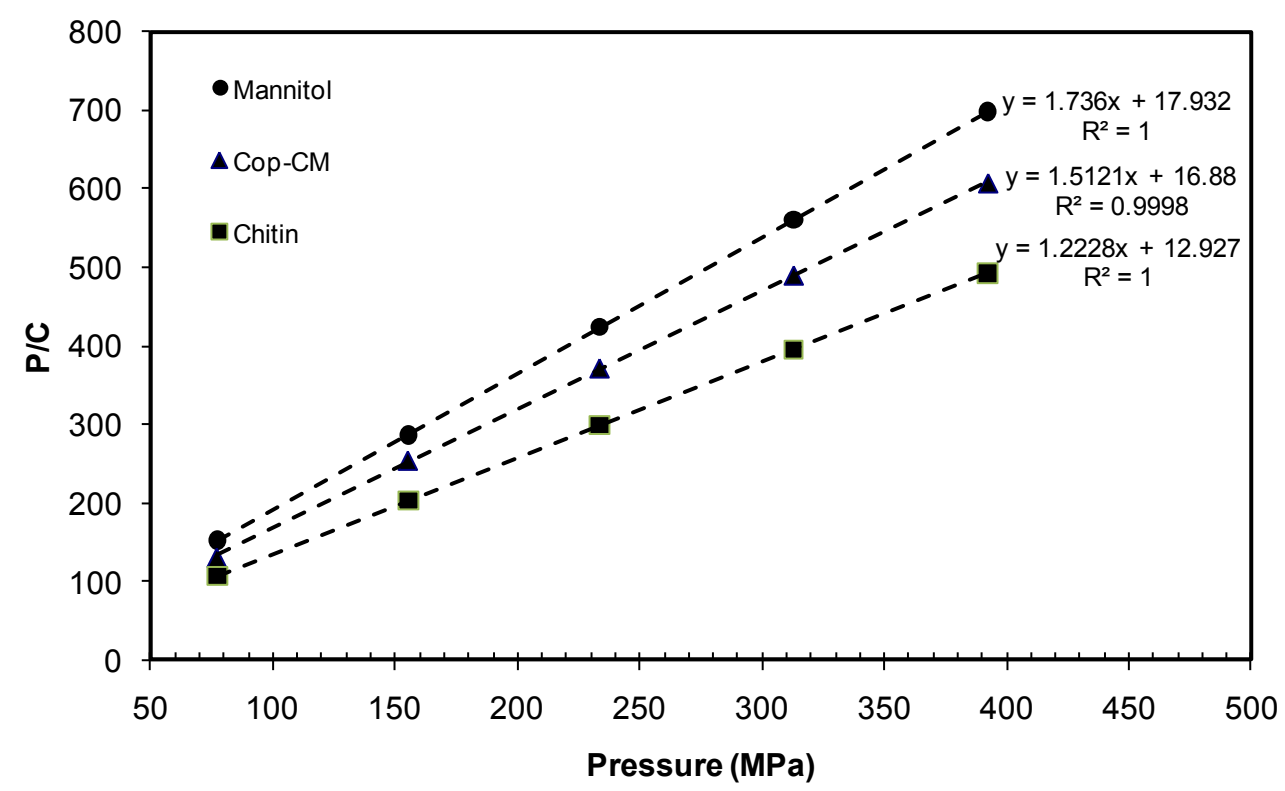

Figure 8. Kawakita plot for co-processed chitin-mannitol (2:8 w/w) excipient (Cop-CM). Tablets were $12 \mathrm{~mm}$ in diameter and $400 \mathrm{mg}$ in weight.

Table 3. Kawakita parameters for mannitol, chitin and co-processed chitin-mannitol $(2: 8 \mathrm{w} / \mathrm{w})$ excipient (Cop-CM).

\begin{tabular}{ccccccc}
\hline \multirow{2}{*}{ Material } & \multicolumn{7}{c}{ Kawakita Parameters } \\
\cline { 2 - 7 } & Slope & Intercept & $\boldsymbol{a}$ & $\boldsymbol{a b}$ & $\boldsymbol{b}$ & $\mathbf{1 / b}$ \\
\hline Mannitol & 1.736 & 17.932 & 0.576 & 0.0558 & 0.0968 & 10.330 \\
Chitin & 1.223 & 12.927 & 0.818 & 0.0774 & 0.0946 & 10.570 \\
Cop-CM & 1.512 & 16.880 & 0.661 & 0.0592 & 0.0896 & 11.164 \\
\hline
\end{tabular}

\subsection{Loading Capacity}

The loading capacity of Cop-CM excipient was studied by using metronidazole as a model drug for an incompressible material. Compressing metronidazole alone (100\% as a reference) gives rise to tablets with low mechanical strength and long disintegration times. However, the effect of increasing the weight ratios of Cop-CM/metronidazole from $0 / 500$ to $500 / 0$ (wt/wt) on these properties were investigated. The results indicated that by increasing the quantity of Cop-CM in the matrix, compactability is improved and the disintegration time is decreased as shown Figure 9. As a result, Cop-CM is capable of accommodate poorly compressible drugs with high loading capacity without affecting the physical and mechanical properties. 


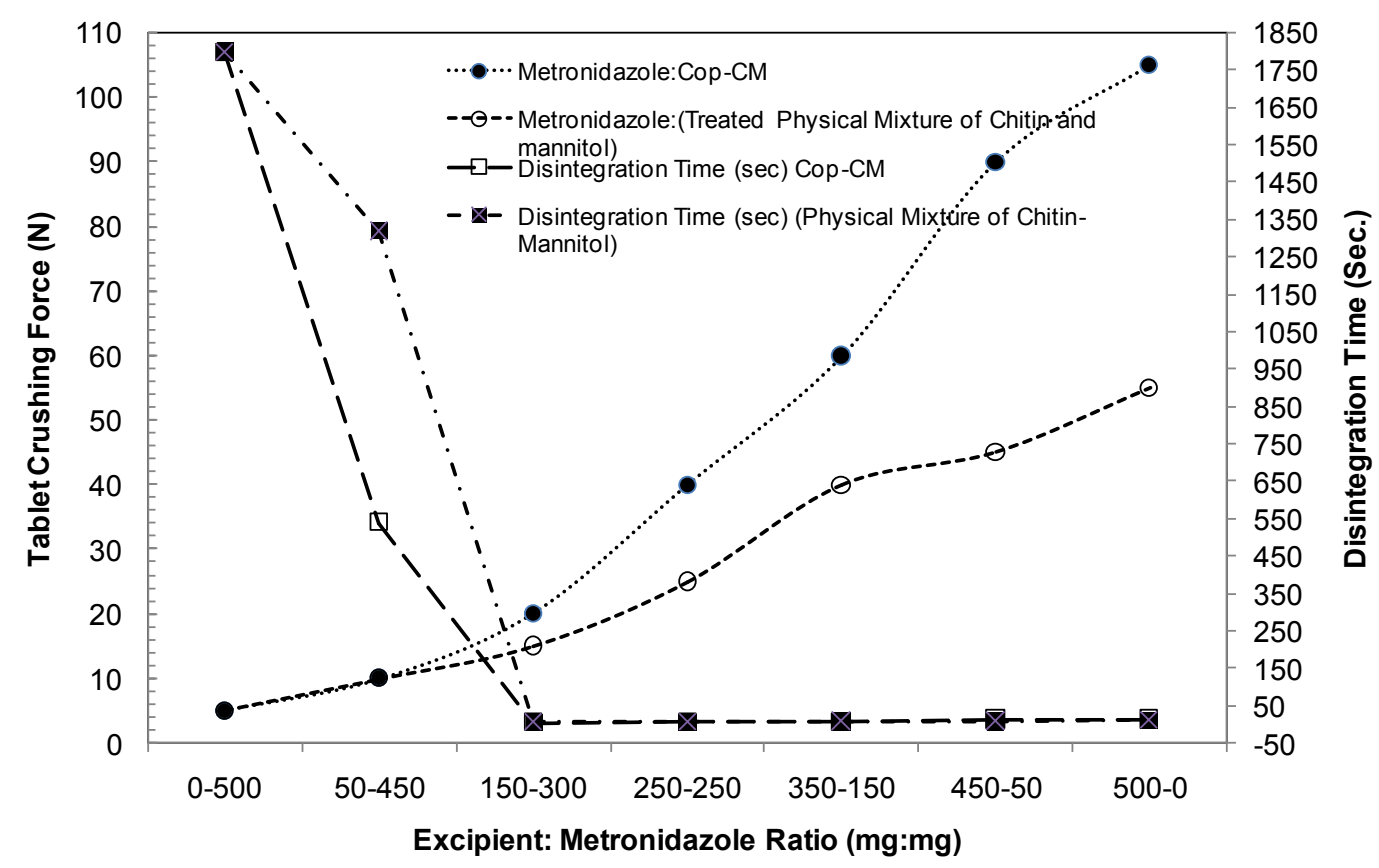

Figure 9. Relationship between tablet crushing force and disintegration time at different Cop-CM: metronidazole ratios using a physical mixture of chitin-mannitol $(2: 8, \mathrm{w} / \mathrm{w})$ as a reference. Data are represented as the mean of $n=10$. Cop-CM represents the co-processed chitin-mannitol $(2: 8 \mathrm{w} / \mathrm{w})$ excipient.

\subsection{Functionality}

The functionality of $\mathbf{C o p}-\mathbf{C M}$ as an excipient was investigated by examining different processing techniques including DC, RC and WG to prepare tablets. The three formulations containing Cop-CM and low strength drugs (montelukast and domperidone) were investigated. Different reported ODT formulations for these two drugs using almost DC technique are summarized in Table 4 [50-56]. In these formulations, several excipients were used to obtain fast disintegrating tablets. Mannitol and microcrystalline cellulose were used as diluents, in addition to deferent superdisintegrants such as croscarmellose sodium, crospovidone, sodium starch glycolate and starch. Combination of talc and magnesium stearate was used as a lubricant system [51,52,54,56]. Furthermore, co-processing of two disintegrants, e.g., crospovidone and sodium starch glycolate, using alcoholic solvent was proposed to obtain fast disintegrating tablets [51]. DC followed by sublimation at $60{ }^{\circ} \mathrm{C}$ was also proposed for ODT formulation [56]. In the present work, co-processed mixture of mannitol and chitin by RC (Cop-CM) is used as a multi-functional excipients (diluents and superdisintegrant), in addition to limited number of excipients (flavor, sweetening agent) and sodium stearyl fumarate as inert lubricant. Although a limited number of excipients were used with Cop-CM as ODT base to improve the taste and to prevent sticking of powder on punches and dies during tablet compression, the fast disintegration properties $(\leq 30$ s) was attained at relatively high tablet crushing force (crushing force: $60-80 \mathrm{~N}$ ) values (Table 5). The tablets obtained from all the processing techniques showed high internal binding and friability $<0.4 \%$ (Table 5). The results indicate that Cop-CM is compressible and preserves its functionality whether utilized in $\mathrm{DC}, \mathrm{RC}$ or $\mathrm{WG}$ formulations. Hence, it can be used as a multifunctional base (binder, filler and disintegrant) in ODT formulations. 
Table 4. Composition of various ODT formulations of montelukast sodium and domperidone.

\begin{tabular}{|c|c|c|c|}
\hline \multicolumn{4}{|c|}{ Montelukast Sodium } \\
\hline Singulair [50] & FDT [51] & ODT [52] & ODT [Present work] \\
\hline $\begin{array}{c}\text { - Mannitol } \\
\text { - Microcrystalline cellulose } \\
\text { - Hydroxypropyl cellulose } \\
\text { - Croscarmellose sodium } \\
\text { - Aspartame } \\
\text { - Red ferric oxide } \\
\text { - Cherry flavor } \\
\text { - Magnesium stearate }\end{array}$ & $\begin{array}{c}\text { - Mannitol } \\
\text { - Microcrystalline cellulose } \\
\text { - Crospovidone } \\
\text { - Sodium starch glycolate } \\
\text { - Sodium saccharin } \\
\text { - Mint flavor } \\
\text { - Talc } \\
\text { - Magnesium stearate }\end{array}$ & $\begin{array}{c}\text { - Mannitol } \\
\text { - Microcrystalline cellulose } \\
\text { - Crospovidone or } \\
\text { - Croscarmellose sodium } \\
\text { - Aspartame } \\
\text { - Talc } \\
\text { - Magnesium stearate }\end{array}$ & $\begin{array}{c}\text { - } \text { Mannitol }^{+} \\
\text {- Chitin } \\
\text { - Strawberry flavor } \\
\text { - Aspartame } \\
\text { - Sodium stearyl fumarate }\end{array}$ \\
\hline \multicolumn{4}{|c|}{ Domperidone } \\
\hline Oroperidys [53] & FDT [54] & FDT [55] & FDT [56] \\
\hline $\begin{array}{c}\text { - Mannitol } \\
\text { - Microcrystalline cellulose } \\
\text { - Maltodextrin } \\
\text { - Croscarmellose sodium } \\
\text { - Glucose } \\
\text { - Mint flavor } \\
\text { - Peppermint gasoline } \\
\text { - Anise oil } \\
\text { - Gasoline mint } \\
\text { - Levomentol } \\
\text { - Glycyrrhizate ammonium } \\
\text { - Gasoline cloves } \\
\text { - Acesulfame potassium } \\
\text { - Arabic gum } \\
\text { - Sulphur dioxide } \\
\text { - Magnesium stearate }\end{array}$ & $\begin{array}{c}\text { - Mannitol } \\
\text { - Microcrystalline cellulose } \\
\text { - Sodium starch glycolate } \\
\text { - Lactose } \\
\text { - Talc } \\
\text { - Magnesium stearate }\end{array}$ & $\begin{array}{c}\text { - Mannitol } \\
\text { - Microcrystalline cellulose } \\
\text { - Sodium starch glycolate } \\
\text { - Lactose } \\
\text { - Crospovidone } \\
\text { - Aspartame } \\
\text { - Citric acid } \\
\text { - Sodium bicarbonate } \\
\text { - Maize starch } \\
\text { - Starch 1500 } \\
\text { - Colloidal anhydrous silica } \\
\text { - Lemon flavor } \\
\text { - Green lake color } \\
\text { - Menthol } \\
\text { - Magnesium stearate }\end{array}$ & $\begin{array}{c}\text { - Mannitol } \\
\text { - Microcrystalline cellulose } \\
\text { - Camphor } \\
\text { - Ispaghula husk } \\
\text { - Povidone K30 } \\
\text { - Crospovidone } \\
\text { - Guar gum } \\
\text { - Aspartame } \\
\text { - Colloidal anhydrous silica } \\
\text { - Orange flavor } \\
\text { - Talc } \\
\text { - Magnesium stearate }\end{array}$ \\
\hline
\end{tabular}

* Co-processed together by alcoholic granulation, ${ }^{+}$Co-processed together by roll compaction, FDT: fast disintegrating tablet, ODT: oro-dispersible tablet. 
Table 5. Composition and physical properties of montelukast and domperidone oro-dispersible tablets.

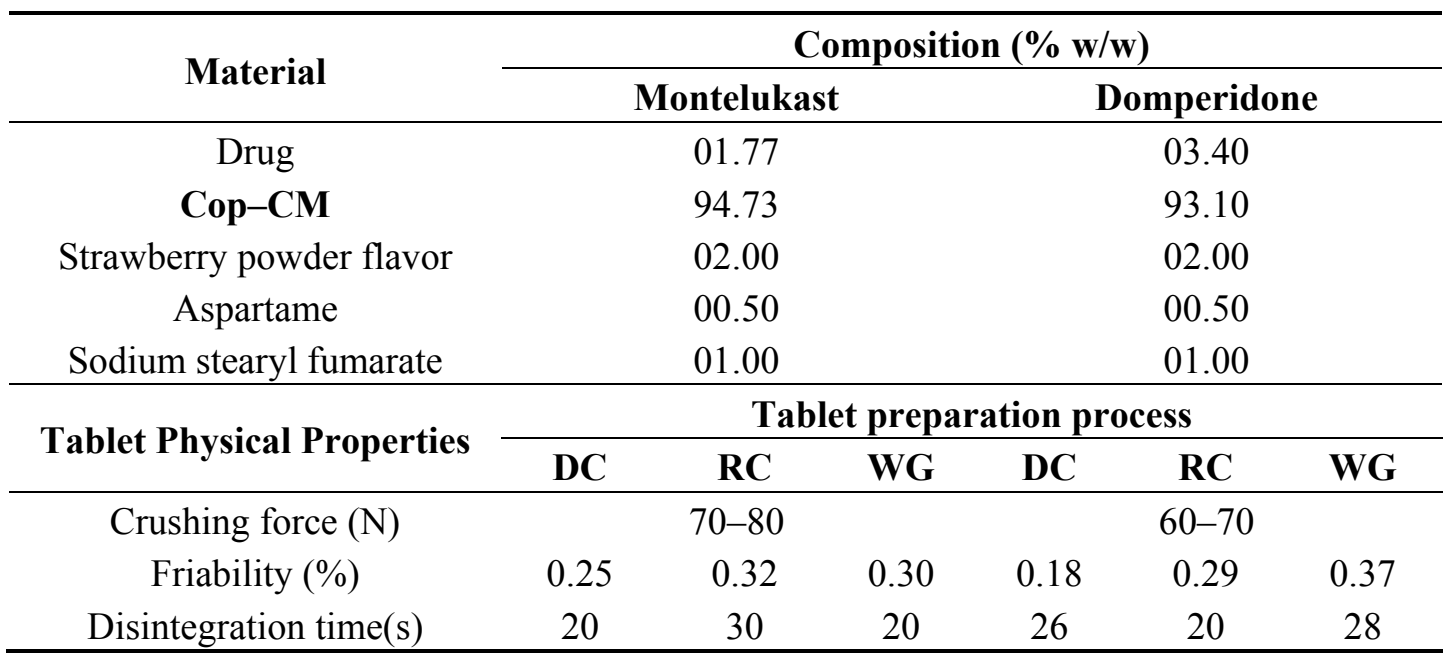

$\mathrm{DC}, \mathrm{RC}$ and WG represent direct compression, roll compaction and wet granulation, respectively.

Cop-CM represents the co-processed chitin-mannitol (2:8 w/w) mixture.

\subsection{Stability Studies}

The stability of montelukast and domperidone tablets prepared by RC procedures in Section 2.9 (functionality) was investigated. Tablets were packed in aluminum/aluminum packs and incubated at $25^{\circ} \mathrm{C}$ and $40{ }^{\circ} \mathrm{C} / 75 \%$ relative humidity for different periods of time and then tested by HPLC methods. The HPLC method was initially tested for system suitability (i.e., peak symmetry, repeatability, and resolution) and for validation parameters (i.e., specificity, stability in solution, linearity and limit of quantitation (LOQ)) according to USP [57] and ICH guidelines [58]. The HPLC results showed a good separation between the drugs and their related impurities. Also, the methods were found to be suitable for stability studies, i.e., the resolution, tailing factors and injection repeatability are within the acceptable criteria. In addition, analysis of samples obtained from stress testing studies in solutions $\left(0.1 \mathrm{~N} \mathrm{NaOH}, 0.1 \mathrm{~N} \mathrm{HCl}\right.$, and $\left.0.3 \% \mathrm{H}_{2} \mathrm{O}_{2}\right)$ indicated that the HPLC methods are stability indicating. The methods were linear over the range of $\pm 50 \%$ of the target concentrations with $r^{2}$ of $>0.99$. The LOQ values are within $0.08-0.4$ and $0.05-0.14$ (w/w \%) for montelukast and domperidone tablets, respectively.

Table 6. Stability data for montelukast and domperidone oro-dispersible tablets.

\begin{tabular}{|c|c|c|c|c|c|}
\hline \multirow{3}{*}{ Product } & \multirow{3}{*}{ Compound/Limit } & \multicolumn{4}{|c|}{ Percentage (w/w) } \\
\hline & & \multicolumn{2}{|c|}{$25^{\circ} \mathrm{C} / 65 \% \mathrm{RH}$} & \multicolumn{2}{|c|}{$40{ }^{\circ} \mathrm{C} / 75 \% \mathrm{RH}$} \\
\hline & & Initial & 24 Months & 3 Months & 6 Months \\
\hline \multirow{5}{*}{ Montelukast } & Drug/90\%-110\% & 99.4 & 104.8 & 102.8 & 98.2 \\
\hline & Drug S-oxide $/ \leq 2.0 \%$ & 0.9 & 1.1 & 3.4 & 3.6 \\
\hline & Drug cis-isomer $/ \leq 0.5 \%$ & 0.1 & 0.5 & 0.1 & 0.1 \\
\hline & Any other $\leq 0.4 \%$ & 0.0 & 0.2 & 0.1 & 0.1 \\
\hline & Total impurities $\leq 3.0 \%$ & 1.0 & 2.0 & 3.6 & 3.8 \\
\hline \multirow{3}{*}{ Domperidone } & Drug/95\%-105\% & 100.1 & - & 100.7 & 101.4 \\
\hline & Any other $/ \leq 0.25 \%$ & 0.06 & - & 0.04 & 0.04 \\
\hline & Total impurities $/ \leq 0.5 \%$ & 0.2 & - & 0.1 & 0.1 \\
\hline
\end{tabular}


As shown in the data in Table 6, no significant decrease in the potency of montelukast and domperidone tablets occurred upon storage at $40{ }^{\circ} \mathrm{C} / 75 \% \mathrm{RH}$ for six months. Montelukast is liable to oxidation by heat [59] forming montelukast S-oxide; however, under shelf-life conditions $\left(25^{\circ} \mathrm{C} / 65 \%\right.$ $\mathrm{RH})$ the degradation content of this product is within the limit (2.0\%). Domperidone tablets display excellent stability when the fraction of impurities does not exceed $0.1 \%$ after 6 months incubation at $40{ }^{\circ} \mathrm{C} / 75 \% \mathrm{RH}$. Both products showed fast disintegration ( $\left.<30 \mathrm{~s}\right)$ and drug release $(>90 \%)$ before and after incubation at $40{ }^{\circ} \mathrm{C} / 75 \% \mathrm{RH}$ indicating the absence of formulation ageing (Table 6).

\section{Experimental Section}

\subsection{Materials}

A-Chitin of average molecular weight $1000 \mathrm{KD}$, degree of acetylation of about 0.96 and a mean particle size of $90 \mu \mathrm{m}$ (Zhejiang Jiande Biochemical, Jiande, China) and D-mannitol (Pearlitol), crystalline grade, with a mean particle size of $160 \mu \mathrm{m}$ (Roquette, Lestrem, France) were used, Purified water of BP grade, Mannogem EZ and Pharmaburst C1 (SPI, Septemes-Les Vallons, France), Isomalt galenIQ $^{\text {TM }} 721$ (BENEO-Palatinit GmbH, Mannheim, Germany), PanExcea MHC200G (Avantor Performance Materials, Inc./Center Valley, PA, USA), sodium stearyl fumarate (JRS, Patterson, NY, USA) and Crospovidone (Polyplasdone XL) with an average particle size of 110-140 (ISP, Wayne, NJ, USA) were also used. All active pharmaceutical ingredients employed i.e., montelukast sodium (Mylan Lab., Hyderabad, India), domperidone (Xinshiji pharma, Fuzhou, Fujian, China) and metronidazole (Hubei Max Pharma, Wuhan, Hubei, China) were of pharmaceutical grade. All other excipients and reagents used were of pharmaceutical or analytical grades, respectively.

\subsection{Methods}

\subsubsection{Preparation of co-Processed Mannitol-Chitin Excipient}

Three co-processed mixtures (each $1 \mathrm{~kg})$ of chitin and mannitol of different ratios $(1: 9,2: 8$ and $3: 7 \mathrm{w} / \mathrm{w})$ were prepared using different processing techniques, i.e., direct mixing, RC and WG.

Direct mixing: The three mixtures were separately passed through a $1000 \mu \mathrm{m}$ mesh sieve (Fritsch, Idar-Oberstein, Germany) and then mixed for $5 \mathrm{~min}$ at $10 \mathrm{rpm}$ using a $1 \mathrm{~L}$ cubic blender equipped with a motor drive machine (Erweka, Heusenstamm, Germany).

Roll compaction: The three mixtures prepared by direct mixing were compacted using a roll compactor equipped with DPS type rolls (TFC-labo, Vector Corporation, Marion, IA, USA), set at about $5 \mathrm{MPa}$ roll pressure, 4 rounds/minutes roll speed and 20 rounds/minutes screw control speed. The compacted powders were collected and passed through either the $710 \mu \mathrm{m}$ or $1000 \mu \mathrm{m}$ sieves using a milling machine equipped with a motor drive machine. Finally the granules were mixed for 5 min at $10 \mathrm{rpm}$ using a 1-L cubic blender equipped with a motor drive machine.

Wet granulation: 350,450 and $550 \mathrm{~mL}$ of $14.5 \%(\mathrm{w} / \mathrm{v})$ of aqueous mannitol solutions were used as granulating agents to prepare the chitin-mannitol mixtures $(1: 9,2: 8$ and 3:7 w/w ratio, respectively). The sieved chitin and the remaining quantity of mannitol were placed in granulation pans (Erweka, Heusenstamm, Germany) and granulated with the mannitol solution using a mixing speed of $150 \mathrm{rpm}$. 
The wet masses were passed through a $9.5 \mathrm{~mm}$ sieve. Drying was performed at $60{ }^{\circ} \mathrm{C}$ using a drying oven (UT6200, Heraeous, Hanau, Germany). The granules were passed through the $1000 \mu \mathrm{m}$ sieve and mixed using the same procedures as used for the RC preparation.

\subsubsection{Characterization of Co-Processed Chitin-Mannitol (Cop-CM)}

Fourier transform infrared spectroscopy: FT-IR measurements were undertaken using an FT-IR instrument (Paragon 1000, Perkin Elmer, Llantrisant, UK) by means of thin pellets containing $1 \mathrm{mg}$ of each sample dispersed in $100 \mathrm{mg}$ of $\mathrm{KBr}$. The spectra were recorded at room temperature as an average of 30 scans, in the $400-4000 \mathrm{~cm}^{-1}$ range with a spectral resolution of $1 \mathrm{~cm}^{-1}$. In order to minimize the effects of traces of $\mathrm{CO}_{2}$ and water vapour from the atmosphere of the sample compartment, the spectrometer was purged with nitrogen.

$X$-ray powder diffractometry: The XRPD patterns were measured using an X-ray diffractometer (PW1729, Philips, Amsterdam, The Netherlands). The radiation was generated using a CoKa source and filtered through Ni filters; a wavelength of $1.79025 \AA$ at $40 \mathrm{~mA}$ and $35 \mathrm{kV}$ was used. The instrument was operated over the $2 \theta$ range of $5-60^{\circ}$. The range and the chart speed were set at $2 \times 103 \mathrm{cycles} / \mathrm{s}$ and $10 \mathrm{~mm} / 2 \theta$, respectively.

Differential scanning calorimetry (DSC): Samples $(\sim 5 \mathrm{mg})$ were hermetically sealed in aluminum pans and scanned over a range temperature of $0-300^{\circ} \mathrm{C}$ at a rate of $5^{\circ} \mathrm{C} / \mathrm{min}$ (DSC 25, Mettler Toledo, Greifensee, Germany). The instrument was calibrated using indium and the calorimetric data were analyzed using STAR software (version 9).

Scanning electron microscopy: The morphology of the samples were determined using a scanning electron microscope (Quanta 200 3D, FEI, Eindhoven, Netherland) operated at an accelerating voltage of $1200 \mathrm{~V}$. The sample $(0.5 \mathrm{mg})$ was mounted onto a $5 \times 5 \mathrm{~mm}$ silicon wafer affixed via graphite tape to an aluminum stub. The powder was then sputter-coated for $105 \mathrm{~s}$ at a beam current of $20 \mathrm{~mA} / \mathrm{dm}^{3}$ with a $100 \AA$ layer of gold/palladium alloy.

Angle of Repose: Angle of Repose (q) was determined using the funnel method [37]. The sample blends were poured through a funnel that could be raised vertically until a maximum cone height $(h)$ was obtained. Radius of the heap ( $r$ ) was measured and then $q$ was calculated using the formula:

$$
q=\tan ^{-1}\left(\frac{h}{r}\right)
$$

Particle size: The particle size distributions for all samples were measured by using a Malvern Mastersizer 2000 instrument (Malvern Instruments Ltd., Worcestershire, UK). Approximately $5 \mathrm{~mL}$ of powder was used for each measurement. The air pressure was set at $2.0 \mathrm{bar}$, and the feed rate was set at 50\%. The particle size distributions D10, D50 and D90 were recorded. Each sample was measured three times.

Bulk density (BD) and tapped density (TD): Approximately $100 \mathrm{~mL}$ of powder was gently poured into a tarred graduated cylinder and the initial volume and weight of the material recorded. The graduated cylinder is placed on a tap density tester (SVM, Tapped volumeter, Erweka, Heusenstamm, Germany) 
and the final volume is recorded after 200 taps. $B D$ and $T D$ are calculated by dividing the initial and final volume of powder by the weight of powder, respectively [37].

Water content: The water content of the powders was measured using a Karl Fischer Titrator (DL38, Mettler Toledo, Greifensee, Switzerland).

pH measurement: The $\mathrm{pH}$ was measured using a a $\mathrm{pH}-$ meter (3030, Jenway, Staffordshire, UK).

Hygroscopicity: Samples (2.5 g) were stored in desiccators containing water saturated salt solutions at room temperature $\left(20^{\circ} \mathrm{C}\right)$ for 10 and 14 days. The media compositions were set according to the Handbook of Chemistry and Physics [60] to obtain relative humidity's (RHs) of 52\%, 62\%, 75\%, 84\% and $95 \%$ using $\mathrm{Ca}\left(\mathrm{NO}_{3}\right) .4 \mathrm{H}_{2} \mathrm{O}, \mathrm{NH}_{4} \mathrm{NO}_{3}, \mathrm{NaCl}, \mathrm{KCl}$ and $\mathrm{Na}_{2} \mathrm{HPO}_{4} .12 \mathrm{H}_{2} \mathrm{O}$, respectively. The samples were withdrawn after a fixed time period and kept at $20^{\circ} \mathrm{C}$ for 1 and $24 \mathrm{~h}$ before weighing and calculating the fractional gain in mass compared to the original mass under the different $\mathrm{RH}$ conditions.

\subsubsection{Physical and Chemical Properties of Tablets Prepared from Cop-CM}

Crushing force, disintegration and friability: The crushing force $6 \mathrm{D}$, Schelenuiger, Thun, Switzerland), disintegration (2T31, Erweka, Heusenstamm, Germany) and friability (Erweka, Heusenstamm, Germany) tests were performed following the general tests in the BP [42].

Influence of particle size on tablet properties: Samples of Cop-CM powders were passed through either $710 \mu \mathrm{m}$ or $1000 \mu \mathrm{m}$ sieves and individually mixed with $1.0 \%(\mathrm{w} / \mathrm{w})$ of sodium stearyl fumarate as a lubricant and then compressed using a single punch tabletting machine (SF3, Chadmach Machinery, Ahmedabad, India) at different crushing force values of 30, 50, 70, 90, 110, 130 and $150 \mathrm{~N}$, using a $10 \mathrm{~mm}$ circular punch to produce tablets of $250 \mathrm{mg}$ weight. The disintegration time and friability were measured at each tablet crushing force point. Some of the commercially available ODT bases (Pharmaburst C1, Isomalt galenIQ ${ }^{\mathrm{TM}}$ 721, Mannogem EZ and PanExcea MHC 200G) in addition to Mannogem EZ and 3\% crospovidone, Isomalt galenIQ ${ }^{\mathrm{TM}} 721$ and 3\% crospovidone powders were lubricated using $1 \% \mathrm{w} / \mathrm{w}$ sodium stearyl fumarate and used as reference materials.

Moisture uptake studies: Moisture uptake studies were conducted in order to assess the physical stability of the ODTs composed of Cop-CM base. Twenty tablets were kept in a desiccator over calcium chloride at $37^{\circ} \mathrm{C}$ for $24 \mathrm{~h}$. The tablets were then weighed and exposed to $75 \%$ relative humidity, at room temperature for 14 days. The required humidity was achieved by the use of saturated sodium chloride solution at the bottom of the desiccators for $72 \mathrm{~h}$. Tablets were weighed and the fractional increase in mass was recorded [60].

Wetting time: A piece of tissue paper ( $8 \mathrm{~cm}$ in diameter), folded twice was placed in a Petri dish ( $8.5 \mathrm{~cm}$ in diameter) containing $6 \mathrm{~mL}$ of water. One tablet was carefully placed on the surface of the tissue paper and allowed to wet completely [60]. The time required for the water to reach the upper surface of the tablet was recorded as the wetting time.

Loading capacity: A study was undertaken to measure the impact of the drug load on the performance of Cop-CM as tablet excipient. Tablets were prepared by DC using a SF3 single punch tablet press machine equipped with D-type tooling. The seven experiments were performed using Cop-CM and metronidazole, containing, $0 \%, 10 \%, 30 \%, 50 \%, 70 \%, 90 \%$ and $100 \%$ (for comparison) of 
metronidazole lubricated with $0.3 \%$ sodium stearyl fumarate. The prepared tablets were circular in shape with a diameter of $12 \mathrm{~mm}$ and a mass of $500 \mathrm{mg}$. Tablets from each experiment were evaluated for crushing force and disintegration time.

Functionality: To investigate the functionality of Cop-CM, two drug models as small strength tablets were studied including montelukast sodium and domperidone. The tablets for the two drugs were prepared by DC, RC as well as WG methods. The montelukast and domperidone tablets contained 1.77\% and $3.4 \%$ of drug and $94.7 \%$ and $93.1 \%$ of Cop-CM, respectively. In addition, both drugs formulations contained strawberry powder $(2.0 \%)$, aspartame $(0.5 \%)$ and sodium stearyl fumarate $(1.0 \%)$. For the DC experiments, montelukast and all excipients, except sodium stearyl fumarate, were first mixed for 2 min and then sodium stearyl fumarate was added and further mixed for another $2 \mathrm{~min}$.

For the RC procedure, montelukast $(1.77 \% \mathrm{w} / \mathrm{w}), \mathbf{C o p}-\mathbf{C M}(25 \% \mathrm{w} / \mathrm{w}$, intra-granular $)$ and sodium stearyl fumarate $(0.6 \% \mathrm{w} / \mathrm{w})$ were compacted by employing a DP roll type compaction using $10 \mathrm{MPa}$ roll pressure, 3 rounds/minutes roll speed and 43 rounds/minutes screw control speed and then passed through a $1000 \mu \mathrm{m}$ sieve. The remaining amount of Cop-CM was added and mixed for 2 min followed by the addition of sodium stearyl fumarate $(0.4 \% \mathrm{w} / \mathrm{w})$. The powder was then further mixed for $2 \mathrm{~min}$.

For the WG procedure, montelukast $(1.77 \% \mathrm{w} / \mathrm{w})$ and Cop-CM $(35 \% \mathrm{w} / \mathrm{w}$, intra-granular) were granulated with $50 \%(\mathrm{w} / \mathrm{v})$ ethanol in water, dried at $60{ }^{\circ} \mathrm{C}$, and then sieved using the $1000 \mu \mathrm{m}$ sieve. The remaining amount of Cop-CM was added and mixed for 2 min; sodium stearyl fumarate (1\%) was then added and mixed for a further $2 \mathrm{~min}$. The same procedures were repeated for domperidone. The prepared mixtures for each drug were compressed at $300 \mathrm{mg}$ tablet weight, for which $10 \mathrm{~mm}$ shallow concave punches and dies were used. Dissolution tests (DT-80; Erweka, Heusenstamm, Germany) for montelukast and domperidone were performed according to the USP [61], FDA [62] and BP [63] published dissolution methods. The released fraction of montelukast and domperidone were determined spectrophotometrically (Du-650i, Beckman Coulter, Brea, CA, USA) by measuring the first derivative absorbance modes at $290 \mathrm{~nm}$ for montelukast and absorbance mode at $280 \mathrm{~nm}$ for domperidone.

Compressibility: Mannitol, chitin and Cop-CM powder samples were compressed using a universal testing machine (RKM 50, PR-F system, ABS Instruments, Tamilnadu, Germany) equipped with $12 \mathrm{~mm}$ round, flat face upper and lower punches as well as dies; punch speed was fixed at $10 \mathrm{~mm} / \mathrm{min}$. Different compression forces from 80 to $390 \mathrm{MPa}$ were applied. Three tablets were prepared to ensure reproducibility. Compression was carried out at $400 \mathrm{mg}$ tablet weight. The compression behavior of the samples was evaluated using Kawakita analysis [43-46].

Stability studies: Montelukast and domperidone tablets prepared by DC were packed in aluminum/aluminum strips and stored at $25{ }^{\circ} \mathrm{C} / 60 \% \mathrm{RH}$ and $40{ }^{\circ} \mathrm{C} / 75 \% \mathrm{RH}$ for 24 and 6 months, respectively. At different interval times, tablets were withdrawn and tested for dissolution and content of drug and its related substances by stability indicating and validated HPLC methods $[57,59,64]$. The HPLC instrument was equipped with a P1000 pump and a UV1000 detector (TSP, Alexandria, VA, USA). For montelukast tablets, a mixture of acetate buffer $(0.385 \%$ ammonium acetate in water adjusted with acetic acid to $\mathrm{pH} 3.5)$ and methanol $(15: 85, \mathrm{v} / \mathrm{v})$ was used as the mobile phase and an octadecylsilyl silica column as the stationary phase $(250 \times 4 \mathrm{~mm}, 10 \mu \mathrm{m})$. UV detection at $254 \mathrm{~nm}$, a flow rate of $1 \mathrm{~mL} / \mathrm{min}$, and $20 \mu \mathrm{L}$ injection volumes of the test solutions $(0.2 \mathrm{mg}$ montelukast $/ \mathrm{mL}$ of $70 \%$ ethanol $)$ 
were used. While for domperidone tablets, methanol and $0.5 \%$ ammonium acetate in water were used as the mobile phases A and B, respectively. A linear gradient elution with a flow rate of $1.5 \mathrm{~mL} / \mathrm{min}$ was programmed as follows: time $0 \mathrm{~min}$ : 30, 70, time $10 \mathrm{~min}$ : 100, 0, and time $12 \mathrm{~min}$ : 100, 0 for mobile phase A and B, respectively. A based-deactivated, end capped L7 column was used as the stationary phase (Hypersil C8 BDS, $100 \times 4.6 \mathrm{~mm}, 3 \mu \mathrm{m}$ ). UV detection at $280 \mathrm{~nm}$ and a $10 \mu \mathrm{L}$ injection volume of the test solutions ( $5 \mathrm{mg}$ domperidone $/ \mathrm{mL}$ of $0.1 \mathrm{M} \cdot \mathrm{HCl}$ in $50 \%$ ethanol) were employed. The HPLC method was initially tested for system suitability (i.e., peak symmetry, repeatability, and resolution) and for validation parameters (i.e., specificity, recovery, stability in solution, linearity, and limit of quantitation (LOQ)) according to USP guidelines [57].

\section{Conclusions}

Co-processing of crystalline mannitol with $\alpha$-chitin by $\mathrm{RC}$ offers an excellent multifunctional base for ODT formulations. The novel excipient displayed fast disintegration and wetting properties over a wide range of tablet crushing force values in comparison with commercially available ODT bases. Regardless of the preparation method (DC, WG or DG), the functionality of the novel excipient was preserved. Moreover, the excipient can accommodate a high amount of drug without affecting its functionality. Utilization of the novel excipient in ODT containing active pharmaceutical ingredients offers very fast disintegration and wetting rates, excellent chemical stability and binding properties. Consequently, the need to use expensive packaging materials for ODT will be eliminated as tablets will no long be prone to breaking during patient use.

\section{Author Contributions}

Adnan A. Badwan, Babur Z. Chowdhry and Stephen A. Leharne conceived and designed the experiments; Nidal Daraghmeh performed the experiments; Nidal Daraghmeh analyzed the data; Adnan A. Badwan contributed reagents/materials/analysis tools; Nidal Daraghmeh and Mahmoud M.H. Al Omari wrote the paper.

\section{Conflicts of Interest}

The authors declare no conflict of interest.

\section{References}

1. Jivraj, M.; Martini, L.G.; Thomson, C.M. An overview of the different excipients useful for the direct compression of tablets. Pharm. Sci. Tech. Today 2000, 3, 58-63.

2. Bhattacharyya, L.; Shuber, S.; Sheehan, S.; William, R. Excipients: background/Introduction. In Excipient Development for Pharmaceutical, Biotechnology, and Drug Delivery Systems; Katdare, A., Chaubal, M.V., Eds.; Informa Healthcare Inc.: New York, NY, USA, 2006; pp. 1-3.

3. Jonwal, N.; Mane, P.; Mokati, S.; Meena, A. Preparation and in vitro evaluation of mouth dissolving tablets of domperidone. Int. J. Pharm. Pharm. Sci. 2010, 3, 975-1491. 
4. U.S. Department of Health and Human Services, Food and Drug Administration, Centre for Drug Evaluation and Research (CDER). Guidance for industry: Orally disintegrating tablets, 2007. Available online: http://www.fda.gov/downloads/Drugs/GuidanceComplianceRegulatoryInformation/ Guidances/ucm070578.pdf (accessed on 2 February 2015).

5. Orodispersible tablets. In European Pharmacopeia, 8th ed.; Council of Europe: Strasbourge, France, 2014; Volume 1, p. 811.

6. Polyplasdone ${ }^{\circledR}$ crospovidone: Superdisintegrants for orally disintegrating and chewable tablets. Available online: http://www.anshulindia.com/pdfs/Polyplasdone\%20for\%20odt\%20Lit.pdf (accessed on 3 February 2015).

7. Deshpande, K.B.; Ganesh, N.S. Formulation and evaluation of orodispersible tablets of propranolol hydrochloride. Int. J. Res. Pharm. Biomed. Sci. 2011, 2, 529-534.

8. Bandari, S.; Mittapalli, R.K.; Gannu, R.; Rao, Y.M. Orodispersible tablets: An overview. Asian J. Pharm. 2008, 2, 2-11.

9. Pfister, W.R.; Ghosh, T.K. Orally disintegrating tablets, products, technologies, and development issues. Pharmaceutical Technology. Available online: http://www.pharmtech.com/node/ 238195?rel=canonical (accessed on 3 February 2015).

10. Schiermeier, S.; Schmidt, P.C. Fast dispersible ibuprofen tablets. Eur. J. Pharm. Sci. 2002, 15, 295-305.

11. Raymond, C.R.; Paul, J.S.; Siân, C.O. Handbook of Pharmaceutical Excipients, 5th ed.; Pharmaceutical Press: Greyslake, IL, USA; American Pharmacists Association: Washington, DC, USA, 2006.

12. Mannogem ${ }^{\circledR} \quad$ Mannitol. Available online: http://www.spipharma.com/product.php? $\mathrm{id}=15 \&$ prodtype $=\mathrm{p}$ (accessed on 3 February 2015).

13. Dolson, L. Low Carb Diets: What are sugar alcohols? Comparisons and blood sugar impact. Available online: http://lowcarbdiets.about.com/od/whattoeat/a/sugaralcohols.htm (accessed on 3 February 2015).

14. Ghosh, T.; Ghosh, A.; Prasad, D. A review on new generation orodispersible tablets and its future prospective. Int. J. Pharm. Pharm. Sci. 2011, 3, 1-7.

15. Erik, L.; Philippe, L.; Jose, L. Pulverulent Mannitol and Process for Preparing it. U.S. Patent 6743447, 1 June 2004.

16. Debord, B.; Lefebvre, C.; Guyothermann, A.M.; Hubert, J.; Bouche, R.; Guyot, J.C. Study of different crystalline forms of mannitol: Comparative behavior under compression. Drug Dev. Ind. Pharm. 1987, 13, 1533-1546.

17. Patil, J.; Vishwajith, V.; Gopal, V. Formulation development and evaluation of chewable tablets containing non-sedating antihistamine. J. Pharm. Sci. Innov. 2012, 1, 112-117.

18. Muzzarelli, R.A.; Tubertini, O. Chitin and chitosan as chromatographic supports and adsorbents for collection of metal ions from organic and aqueous solutions and sea-water. Talanta 1969, 16, 1571-1577.

19. Datta, P.K.; Basu, P.S.; Datta, T.K. Isolation and characterization of Vicia faba lectin affinity purified on chitin column. Prep. Biochem. 1984, 14, 373-387.

20. Songkroah, C.; Nakbanpote, W.; Thiravetyan, P. Recovery of silver-thiosulphate complexes with chitin. Proc. Biochem. 2004, 39, 1553-1559. 
21. Krajewska, B. Application of chitin- and chitosan-based materials for enzyme immobilizations: A review. Enzyme Microb. Tech. 2004, 35, 126-139.

22. Yusof, N.L.; Wee, A.; Lim, L.Y.; Khor, E. Flexible chitin films as potential wound-dressing materials: wound model studies. J. Biomed. Mater. Res. A 2003, 66, 224-232.

23. Rathke, T.D.; Hudson, S.M. Review of chitin and chitosan as fiber and film formers. J. Macromol. Sci. C 1994, 34, 375-437.

24. Pierson, Y.; Chen, X.; Bobbink, F.D.; Zhang, J.; Yan, N. Acid-catalyzed chitin liquefaction in ethylene glycol. ACS Sustain. Chem. Eng. 2014, 2, 2081-2089.

25. Chen, X.; Chew, S.L.; Kerton, F.M.; Yan, N. Direct conversion of chitin into a $N$-containing furan derivative. Green Chem. 2014, 16, 2204-2212.

26. Bobbink, F.D.; Zhang, J.; Pierson, Y.; Chen, X.; Yan, N. Conversion of chitin derived N-acetyl-Dglucosamine (NAG) into polyols over transition metal catalysts and hydrogen in water. Green Chem. 2015, 17, 1024-1031.

27. Daraghmeh, N.H.; Chowdhry, B.Z.; Leharne, S.A.; Al Omari, M.M.; Badwan, A.A. Chitin. In Profiles of Drug Substances, Excipients and Related Methodology; Brittain, H., Ed.; Elsevier Inc.: New York, NY, USA, 2011; Volume 36, pp. 35-102.

28. Muzzarelli, R.A.A. Chitin; Pergamon Press: Oxford, UK, 1977.

29. Gupta, P.; Nachaegari, S.K.; Bansal, A.K. Improved Excipient Functionality by Co-Processing. In Excipient Development for Pharmaceutical, Biotechnology, and Drug Delivery Systems; Katdare, A., Chaubal, M.V., Eds.; Informa Healthcare Inc.: New York, NY, USA, 2006; pp. 109-124.

30. Rashid, I.; Daraghmeh, N.; Al-Remawai, M.; Leharne, S.A.; Chowdhry, B.Z.; Badwan, A. Characterization of chitin-metal silicates as binding superdisintegrants. J. Pharm. Sci. 2009, 98, 4887-4901.

31. Rashid, I.; Al-Remawi, M.; Eftaiha, A.; Badwan, A. Chitin-silicon dioxide coprecipitate as a novel superdisintegrant. J. Pharm. Sci. 2008, 97, 4955-4969.

32. Daraghmeh, N.; Rashid, I.; Al Omari, M.M.H.; Leharne, S.A.; Chowdhry, B.Z.; Badwan, A. Preparation and characterization of a novel co-processed excipient of chitin and crystalline mannitol. AAPS Pharm. Sci. Tech. 2010, 11, 1558-1571.

33. Kablan, T; Clément, Y. Bi, Y.; Françoise, K.A.; Mathias, O.K. Determination and modelling of moisture sorption isotherms of chitosan and chitin. Acta Chim. Slov. 2008, 55, 677-682.

34. Silva, S.S.; Duarte, A.R.C.; Carvalho, A.P.; Mano, J.F.; Reis, R.L. Green processing of porous chitin structures for biomedical applications combining ionic liquids and supercritical fluid technology. Acta Biomater. 2011, 7, 1166-1172.

35. Kharade, S.; Bhutkar, M.A. Novel superdisintegrants interpolymeric chitosan-alginate complex and chitin in the formulation of orodispersible tablets. Int. J. Pharm. Res. Dev. 2013, 5, 87-94.

36. Glenn, T.C.; Bruno, C.H. A Comparison of Physical and Mechanical Properties of Common Tableting Diluents. In Excipient Development for Pharmaceutical, Biotechnology, and Drug Delivery Systems; Katdare A., Chaubal M.V., Eds.; Informa Healthcare Inc.: New York, NY, USA, 2006; pp. 127-151. 
37. Khinchi, M.P.; Gupta, M.K.; Bhandari, A.; Sharma, N.; Agarwal, D. Design and development of orally disintegrating tablets of famotidine prepared by direct compression method using different superdisintegrants. J. App. Pharm. Sci. 2011, 1, 50-58.

38. Nyström, C.; Alderborn, G.; Duberg, M.; Karehill, P.G. Bonding surface area and bonding mechanism-two important factors for the understanding of powder compactibility. Drug Dev. Ind. Pharm. 1993, 19, 2143-2196.

39. Alderborn, G.; Börjesson, E.; Glazer, M.; Nyström, C. Studies on direct compression of tablets. XIX: The effect of particle size and shape on the mechanical strength of sodium bicarbonate tablets. Acta Pharm. Suec. 1988, 25, 31-40.

40. Juppo, A.M. Change in porosity parameters of lactose, glucose and mannitol granules caused by low compression force. Int. J. Pharm. 1996, 130, 149-157.

41. Bhowmik, D.; Chiranjib, B.; Krishnakanth, P.; Chandira, R.M. Fast dissolving tablet: An overview. J. Chem. Pharm. Res. 2009, 1, 163-177.

42. Disintegration, Friability of Uncoated Tablets, Resistance to Crushing of Tablets. In British Pharmacopeia; The Stationary Office: London, UK, 2014; Volume V, pp. A333-A378, A493, A495.

43. Kawakita, K.; Lüdde, K.H. Some considerations on powder compression equations. Powder Technol. 1071, 4, 61-68.

44. Shivanand, P.; Sprockel, O.L. Compaction behaviour of cellulose polymers. Powder Technol. 1992, 69, 177-184.

45. Lin, C.; Cham, T. Compression behaviour and tensile strength of heat-treated polyethylene glycols. Int. J. Pharm. 1995, 118, 169-179.

46. Nordström, J.; Klevan, I.; Alderborn, G. A particle rearrangement index based on the Kawakita powder compression equation. J. Pharm. Sci. 2008, 98, 1053-1063.

47. Adetunji, O.A.; Odeniyi, M.A.; Itiola, O.A. Compression, mechanical and release properties of chloroquine phosphate tablets containing corn and trifoliate yam starches as binders. Trop. J. Pharm. Res. 2006, 5, 589-596.

48. Martins, E.; Christiana, I.; Olobayo, K. Effect of grewia gum on the mechanical properties of paracetamol tablet formulations. African J. Pharm. Pharmacol. 2008, 2, 1-6.

49. Zhang, Y.; Law, Y.; Chakrabarti, S. Physical properties and compact analysis of commonly used direct compression binders. AAPS Pharm. Sci. Tech. 2005, 4, Article 62.

50. U.S. Food and Drug Administration. Singulair ${ }^{\circledR}$ (montelukast sodium) Tablets, Chewable Tablets, and Oral Granules. Available online: http://www.accessdata.fda.gov (accessed on 29 January 2015).

51. Mahesh, E.; Kiran Kumar, G.B.; Ahmed, M.G.; Kiran Kumar, P. Formulation and evaluation of montelukast sodium fast dissolving tablets. Asian J. Biomed. Pharm. Sci. 2012, 2, 75-82.

52. Chhajed, M.; Tiwari, D.; Malve, A.; Godhwani, T.; Chhajed, A.; Shrivastava, A.K. Formulation development and evaluation of montelukast sodium orodispersible tablets: A new trend in asthma treatmentInt. J. Pharm. Res. Sci. 2012, 1, 127-139.

53. Oroperidys $10 \mathrm{mg}$ cp Orodispers, Vidal Homepage. Available online: http://www.vidal.fr/ Medicament/oroperidys-75053.htm (accessed on 29 January 2015).

54. Parmar, R.B.; Baria, A.H.; Tank, H.M.; Faldu, S.D. Formulation and evaluation of domperidone fast dissolving tablets. Int. J. Pharm. Tech. Res. 2009, 1, 483-487. 
55. Islam, A.; Haider, S.S.; Reza, M.S. Formulation and evaluation of orodispersible tablet of domperidone. Dhaka Univ. J. Pharm. Sci. 2011, 10, 117-122.

56. Sutradhar, K.B.; Akhter, D.T.; Uddin, R. Formulation and evaluation of taste masked oral dispersible tablets of domperidone using sublimation method. Int. J. Pharm. Pharm. Sci. 2012, 4, 727-732.

57. Validation of Compendia Procedures <1225>. In United States Pharmacopeia and National Formulary (USP37-NF32); US Pharmacopoeia Convention: Rockville, MD, USA, 2014; Volume I, pp. 1157-1162.

58. Validation of Analytical Procedures: Text and Methodology, European Medicines Agency. Available online: http://www.ema.europa.eu/docs/en_GB/document_library/Scientific_guideline/ 2009/09/WC500002662.pdf (accessed on 3 February 2015).

59. Al Omari, M.M.; Zoubi, R.M.; Hasan, E.I.; Khader, T.Z.; Badwan, A.A. Effect of light and heat on the stability of montelukast in solution and in its solid state. J. Pharm. Biomed. Anal. 2007, 45, 465-471.

60. Weast, R.C. Handbook of Chemistry and Physics, 55th ed.; CRC Press: Boca Raton, FL, USA, 1974-1975; p. E-46.

61. Dissolution <711>. In United States Pharmacopeia and National Formulary (USP37-NF32); US Pharmacopoeia Convention: Rockville, MD, USA, 2014; Volume 1, pp. 344-351.

62. Dissolution Method; U.S. Food and Drug Administration: Rockville, MD, USA. Available online: http://www.accessdata.fda.gov/scripts/cder/dissolution/dsp_SearchResults_Dissolutions.cfm?Print All=1 (accessed on 3 February 2015).

63. Domperidone Tablets. In British Pharmacopeia; The Stationary Office: London, UK, 2014; Volume III, p. 469.

64. Badwan, A.A. The Jordanian Pharmaceutical Manufacturing Co. (JPM), Amman, Jordan. Unpublished work, 2014.

(C) 2015 by the authors; licensee MDPI, Basel, Switzerland. This article is an open access article distributed under the terms and conditions of the Creative Commons Attribution license (http://creativecommons.org/licenses/by/4.0/). 